EGG-CIET-11061

\title{
GIS Analysis of the Siting Criteria for the Mixed and Low-Level Waste Treatment Facility and the Idaho Waste Processing Facility
}

Reed L. Hoskinson

Published January 1994

\section{Idaho National Engineering Laboratory \\ EG\&G Idaho, Inc. \\ Idaho Falls, Idaho 83415}

\footnotetext{
Prepared for the

U.S. Department of Energy

Office of Environmental Restoration and Waste Management

Under DOE Idaho Field Office

Contract DE-AC07-76ID01570
} 


\begin{abstract}
This report summarizes a study conducted using the Arc/Info geographic information system (GIS) to analyze the criteria used for site selection for the Mixed and Low-Level Waste Treatment Facility (MLLWTF) and the Idaho Waste Processing Facility (IWPF). The purpose of the analyses was to determine, based on predefined criteria, the areas on the INEL that best satisfied the criteria. The coverages used in this study were produced by importing the AutoCAD files that produced the maps for a preliminary site selection draft report into the GIS. The files were then converted to Arc/Info ${ }^{\infty}$ GIS format. The initial analysis was made by considering all of the criteria as having equal importance in determining the areas of the INEL that would best satisfy the requirements. Another analysis emphasized four of the criteria as "must" criteria which had to be satisfied. Additional analyses considered other criteria that were considered for, but not included in the predefined criteria. This GIS analysis of the siting criteria for the IWPF and MLLWTF provides a logical, repeatable, and defersible approach to the determination of candidate locations for the facilities. The results of the analyses support the location of the Candidate Locations.
\end{abstract}




\section{CONTENTS}

ABSTRACT $\ldots \ldots \ldots \ldots \ldots \ldots \ldots \ldots \ldots \ldots \ldots \ldots \ldots \ldots \ldots \ldots \ldots \ldots \ldots \ldots$

ACRONYMS $\ldots \ldots \ldots \ldots \ldots \ldots \ldots \ldots \ldots \ldots \ldots \ldots \ldots \ldots \ldots \ldots \ldots$ vii

1. INTRODUCTION $\ldots \ldots \ldots \ldots \ldots \ldots \ldots \ldots \ldots \ldots \ldots \ldots \ldots \ldots \ldots \ldots \ldots \ldots \ldots$

2. GENERAL OVERVIEW OF

GEOGRAPHIC INFORMATION SYSTEMS $\ldots \ldots \ldots \ldots \ldots$

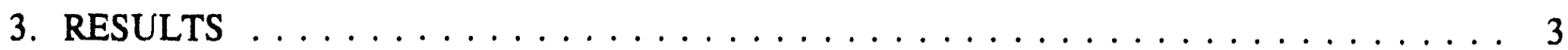

3.1 Detailed Description of the Criteria $\ldots \ldots \ldots \ldots \ldots \ldots \ldots \ldots \ldots \ldots$

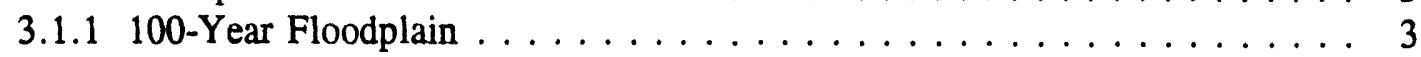

3.1.2 Above the 100 Year Flooding Elevation $\ldots \ldots \ldots \ldots \ldots \ldots, 3$

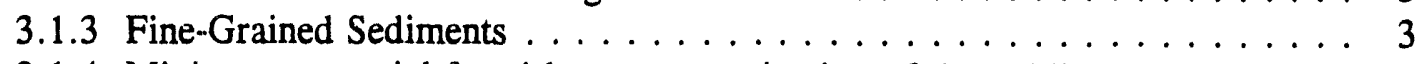

3.1.4 Minimum potential for airborne contamination of the public $\ldots \ldots \ldots 7$

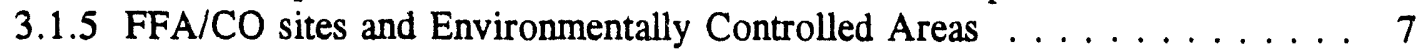

3.1.6 Within 1 mile of Category I facilities and/or existing/proposed reactors . . . 7

3.1.7 Wind corridors of existing facilities $\ldots \ldots \ldots \ldots \ldots \ldots \ldots 7$

3.1 .8 Most vulnerable to lava flows $\ldots \ldots \ldots \ldots \ldots \ldots \ldots \ldots \ldots$

3.1 .9 Most vulnerable to volcanic fissuring $\ldots \ldots \ldots \ldots \ldots \ldots \ldots 7$

3.1.10 Within One Mile of a Capable Fault $\ldots \ldots \ldots \ldots \ldots \ldots \ldots 14$

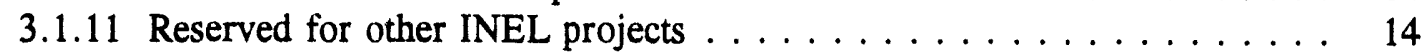

3.1 .12 Not above aquifer $\ldots \ldots \ldots \ldots \ldots \ldots \ldots \ldots \ldots \ldots \ldots$

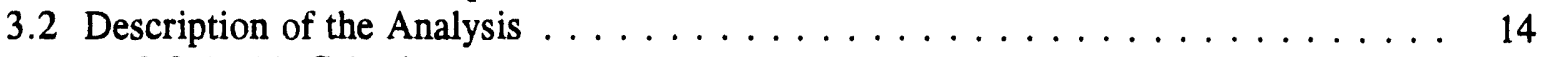

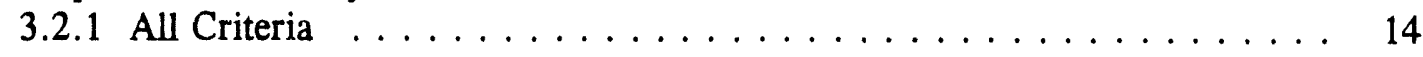

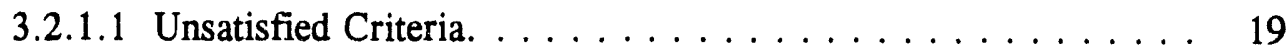

3.2.2 Selected Criteria $\ldots \ldots \ldots \ldots \ldots \ldots \ldots \ldots \ldots \ldots \ldots \ldots$

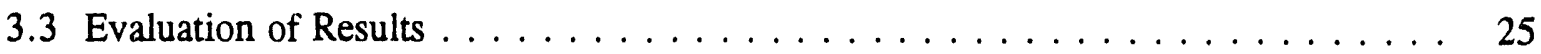

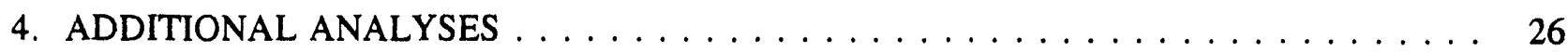

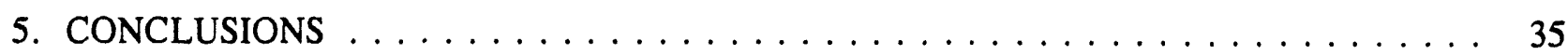

\section{FIGURES}

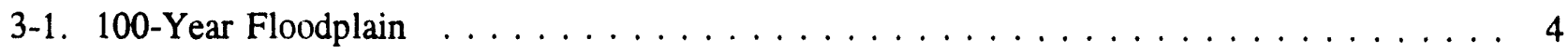

3-2. Above the 100 Year Flooding Elevation $\ldots \ldots \ldots \ldots \ldots \ldots \ldots \ldots \ldots \ldots \ldots$

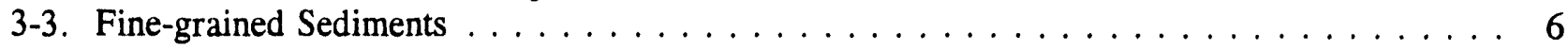

$3-4$. Minimum potential for airborne contamination to the public $\ldots \ldots \ldots \ldots \ldots$

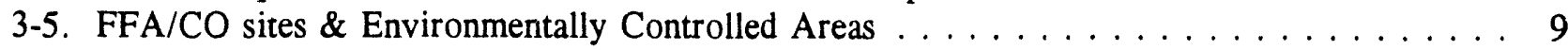

3-6. Within 1 mile of Category I facilities and/or existing/proposed reactors $\ldots \ldots \ldots \ldots 10$

3-7. Wind corridors of existing facilities $\ldots \ldots \ldots \ldots \ldots \ldots \ldots \ldots \ldots \ldots \ldots \ldots \ldots$

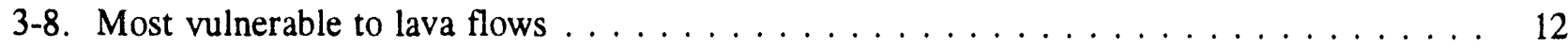


3-9. Most vulnerable to volcanic fissuring $\ldots \ldots \ldots \ldots \ldots \ldots \ldots \ldots \ldots \ldots \ldots \ldots \ldots$

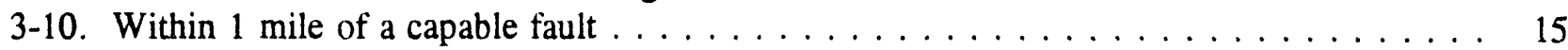

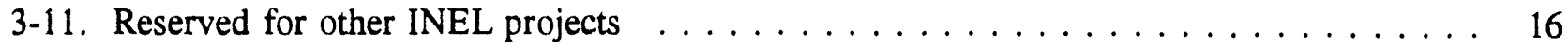

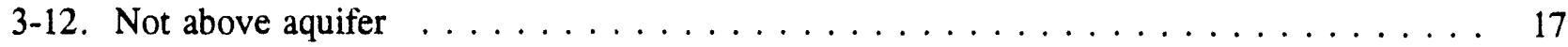

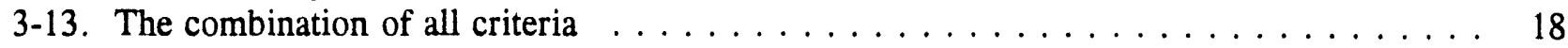

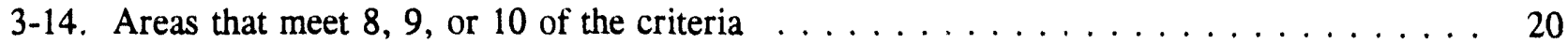

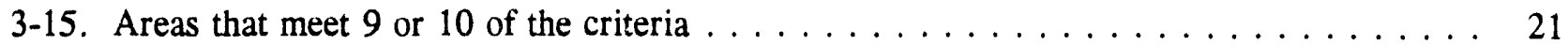

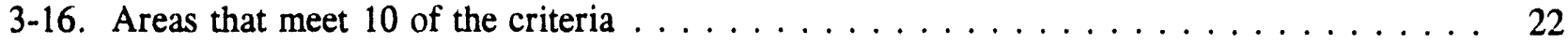

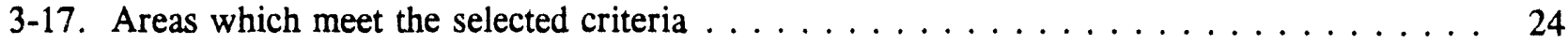

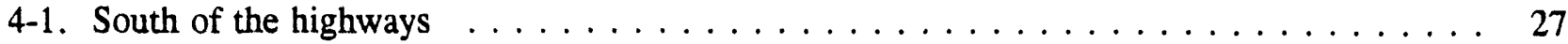

4-2. Selected criteria and "south of the highway" as a criterion $\ldots \ldots \ldots \ldots \ldots \ldots 28$

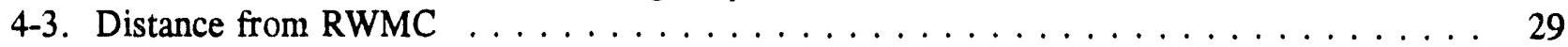

4-4. Selected criteria and distance from RWMC $\ldots \ldots \ldots \ldots \ldots \ldots \ldots \ldots \ldots \ldots$

4-5. Within one mile of a public road $\ldots \ldots \ldots \ldots \ldots \ldots \ldots \ldots \ldots \ldots \ldots \ldots \ldots$

$4-6$. Within two miles of the INEL boundary $\ldots \ldots \ldots \ldots \ldots \ldots \ldots \ldots \ldots \ldots \ldots \ldots \ldots$

4-7. Areas best meeting all criteria (top 4 levels) $\ldots \ldots \ldots \ldots \ldots \ldots \ldots \ldots \ldots \ldots \ldots$

4-8. Areas best meeting all criteria (top 3 levels) $\ldots \ldots \ldots \ldots \ldots \ldots \ldots \ldots \ldots \ldots$

\section{TABLES}

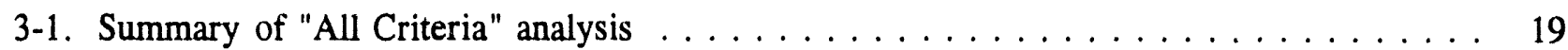

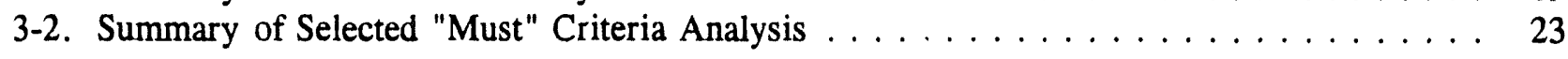




\section{ACRONYMS}

$\begin{array}{ll}\text { CAD } & \text { Computer Aided Design } \\ \text { CAM } & \text { Computer Aided Mapping } \\ \text { CIET } & \text { Center for Integrated Environmental Technologies } \\ \text { COCA } & \text { Consent Order and Compliance Agreement } \\ \text { DOE-ID } & \text { Department of Energy - Idaho Field Office } \\ \text { DOT } & \text { Department of Transportation } \\ \text { EPA } & \text { Environmental Protection Agency } \\ \text { ESRP } & \text { Eastern Snake River Plain } \\ \text { FFA/CO } & \text { Federal Facility Agreement and Consent Order } \\ \text { GIS } & \text { geographic information system } \\ \text { INEL } & \text { Idaho National Engineering Laboratory } \\ \text { IWPF } & \text { Idaho Waste Processing Facility } \\ \text { MLLWTF } & \text { Mixed and Low-Level Waste Treatment Facility } \\ \text { RWMC } & \text { Radioactive Waste Management Complex }\end{array}$




\section{GIS Analysis of the Siting Criteria for the Mixed and Low-Level Waste Treatment Facility and the Idaho Waste Processing Facility}

\section{INTRODUCTION}

This report presents the results of using the $\mathrm{Arc} / \mathrm{Info}^{\oplus}$ geographic information system (GIS) to analyze the siting criteria for the Mixed and Low-Level Waste Treatment Facility (MLLWTF) and the Idaho Waste Processing Facility (IWPF). The purpose of the analyses was to determine, based on predefined criteria, the areas on the INEL that best satisfied those criteria.

The twelve criteria used in the siting study were:

above the 100 year flooding elevation
fine-grained sediments
minimum potential for airborne contamination of the public
FFA/CO sites \& Environmentally Controlled Areas
within 1 mile of Category I facilities and/or existing/proposed reactors
wind corridors of existing facilities
most vulnerable to lava flows
- most vulnerable to volcanic fissuring
- rithin 1 mile of a capable fault
not above the aquifer

Four of the criteria were considered "must" criteria, in that the selected areas must satisfy those criteria. They are that the Candidate Locations

- must not contain any portions of the 100 year floodplain,

- must not contain any portions of the FFA/CO sites \& Environmentally Controlled Areas,

- must not contain any portions of the areas within 1 mile of Category I facilities and/or existing/proposed reactors, and

- all candidate areas must be within the areas above the 100 year flooding elevation. 


\section{GENERAL OVERVIEW OF GEOGRAPHIC INFORMATION SYSTEMS}

A GIS is a computer system which combines the data storage/retrieval capability of data base technology with the spatial drawing capability of computer mapping, and has the added capability to do spatial analyses of the data. Spatial data sets provide geographic positions of features, related to a known coordinate system, associated with attribute data about the features, which may be independent of position. An example of this would be the geographic data coordinates of a well location, along with attribute data for that well such as depth, diameter, well name, date drilled, etc. Another example would be the geographic outline of a floodplain, and attributes denoting the area included in the floodplain.

The spatial features can have point, line, or area (polygon) characteristics. A GIS can store and manipulate these types of spatial data, along with the associated attributes data. It is this spatial analysis that sets GIS apart from previous Computer Aided Design (CAD) and Computer Aided Mapping (CAM) technologies.

There are two data structure technologies used to organize spatial data in a GIS, the raster data structure and the vector data structure.

The raster data structure partitions the spatial area into a set of grid cells (usually square) in rows and columns. Each cell is assigned a code describing the feature contained within the cell. The cell size is constant for all cells, and is usually a function of the resolution available or needed, or computer memory restrictions. Explicit $x, y$ coordinates are not given to each cell because the cell location is implicit in its row and column location. Image processing systems, specifically those developed to manipulate remotely sensed digital data from satellites, have many of the functions that make them most suitable as raster systems. However, the cell-by-cell nature of the raster structure makes it difficult to retrieve information about linear features (such as the length of a river or road) or to traverse a network (such as a train route or a watershed).

Vector data structures use a series of $x, y$ coordinates to describe point, line, and polygon features. The vector data structure also allows for storage of data for multiple features for the coordinates. In addition, the information about the connections and relationships among the features (the topology) is calculated and stored with the coordinates. This allows the user the ability to derive relationships such as adjacency and connectivity. Although vector data structures are computationally more demanding than raster, they are more widely used because of the greater information inherent in the data. The Arc/Info GIS is a vector data structure system.

Each GIS data set is normally limited to one thematic topic or category of data, and is commonly referred to as a "coverage" or "layer". Examples of coverages are the 100 Year Floodplain, etc., as listed earlier for this siting study.

The primary activity of a GIS is to apply spatial analysis tools to combinations of data categories in order to model and reach conclusions about problems. These tools, which are a part of the GIS software, allow for the spatial combining of data sets (overlaying, intersecting, joining, etc.) and for creation of additional attributes based on logical and mathematical analyses of combinations of feature attributes. 


\section{RESULTS}

\subsection{Detailed Description of the Criteria}

The coverages used in this study were produced by importing the AutoCAD files that produced the maps for the preliminary site selection draft report. The files were then converted to Arc/Info ${ }^{\otimes} \mathrm{GIS}$ format.

On each of the following figures, the Candidate Locations \#1, \#3, \#5, and $\# 9$ for the IWPF and MLLWTF are indicated in solid black. The areas of the INEL that satisfy the individual criterion are shaded.

\subsubsection{0-Year Floodplain}

An official delineation of the 100-year floodplain for the Big Lost River and its tributaries has not been established on the INEL. Work is presently underway to collect accurate topography of the Big Lost River drainage for use in the computation of the 100-year floodplain.

To fulfill the present requirement to consider the floodplain, the results of a prior study of the flooding effects that would result from failure of the Mackay Dam, located upstream of the INEL on the Big Lost River, were used (Figure 3-1).

\subsubsection{Above the 100 Year Flooding Elevation}

The areas shown in Figure 3-2 were selected on the basis of two potential sources of flooding:

a) a flood wave moving down the channel of the Big Lost River, and

b) accumulation of local runoff.

The potential from flooding from the Big Lost River was evaluated for each square mile by comparing the lowest elevation in the section to the elevation of the nearest point of the flood. Potential for flooding from runoff assessed the amount of upland, streams, and average slope for each section. Each section was included or removed as a whole.

\subsubsection{Fine-Grained Sediments}

Available information about sediment types and thicknesses from the ground surface to the Eastern Snake River Plain (ESRP) aquifer were used to delineate these areas (Figure 3-3), mostly based on surficial geology maps.

These areas reflect surficial deposits, and do not take into account sedimentary interbeds among the basalt flows within the vadose zone. 


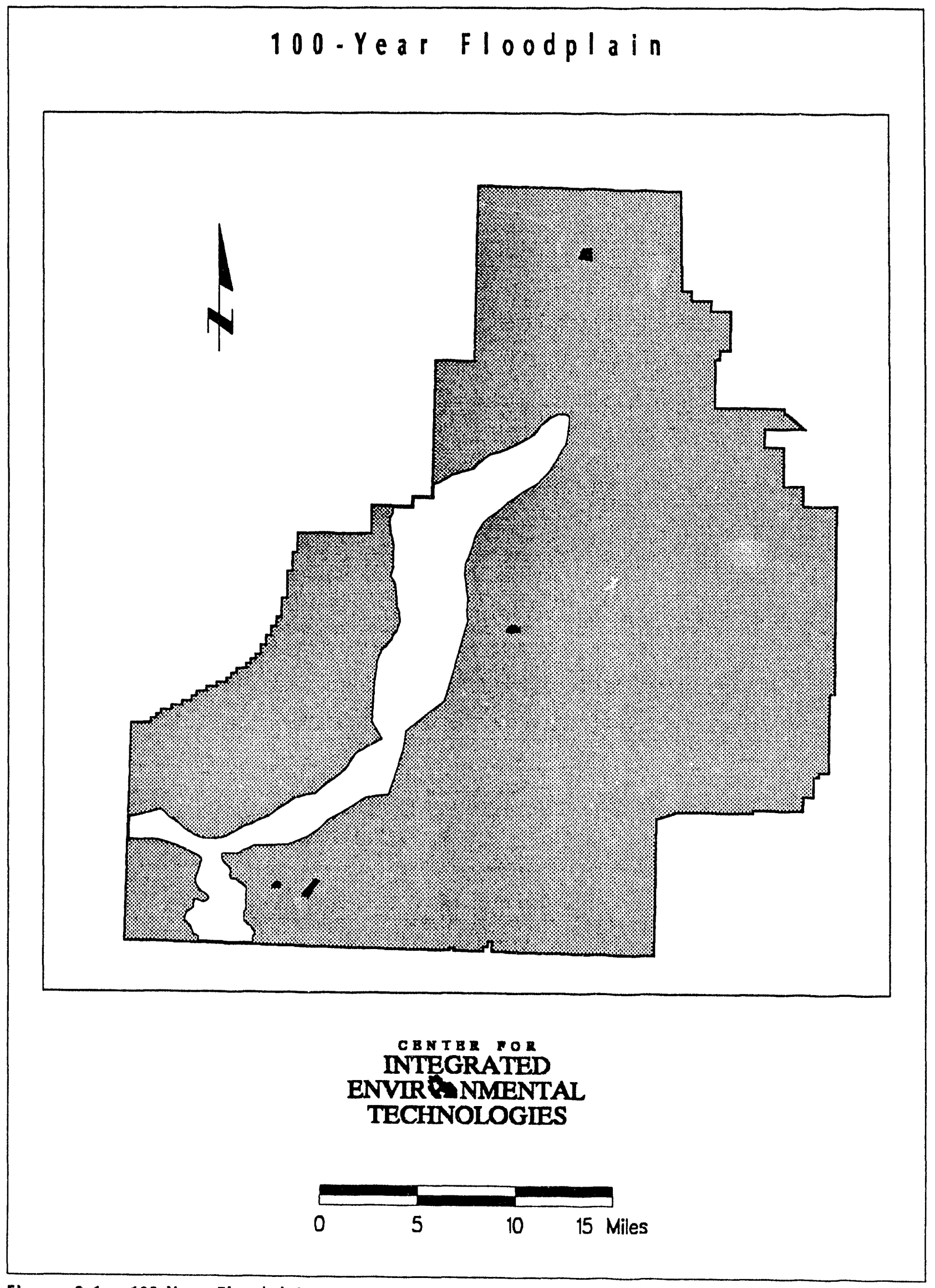

Figure 3-1. 100-Year Floodplain 


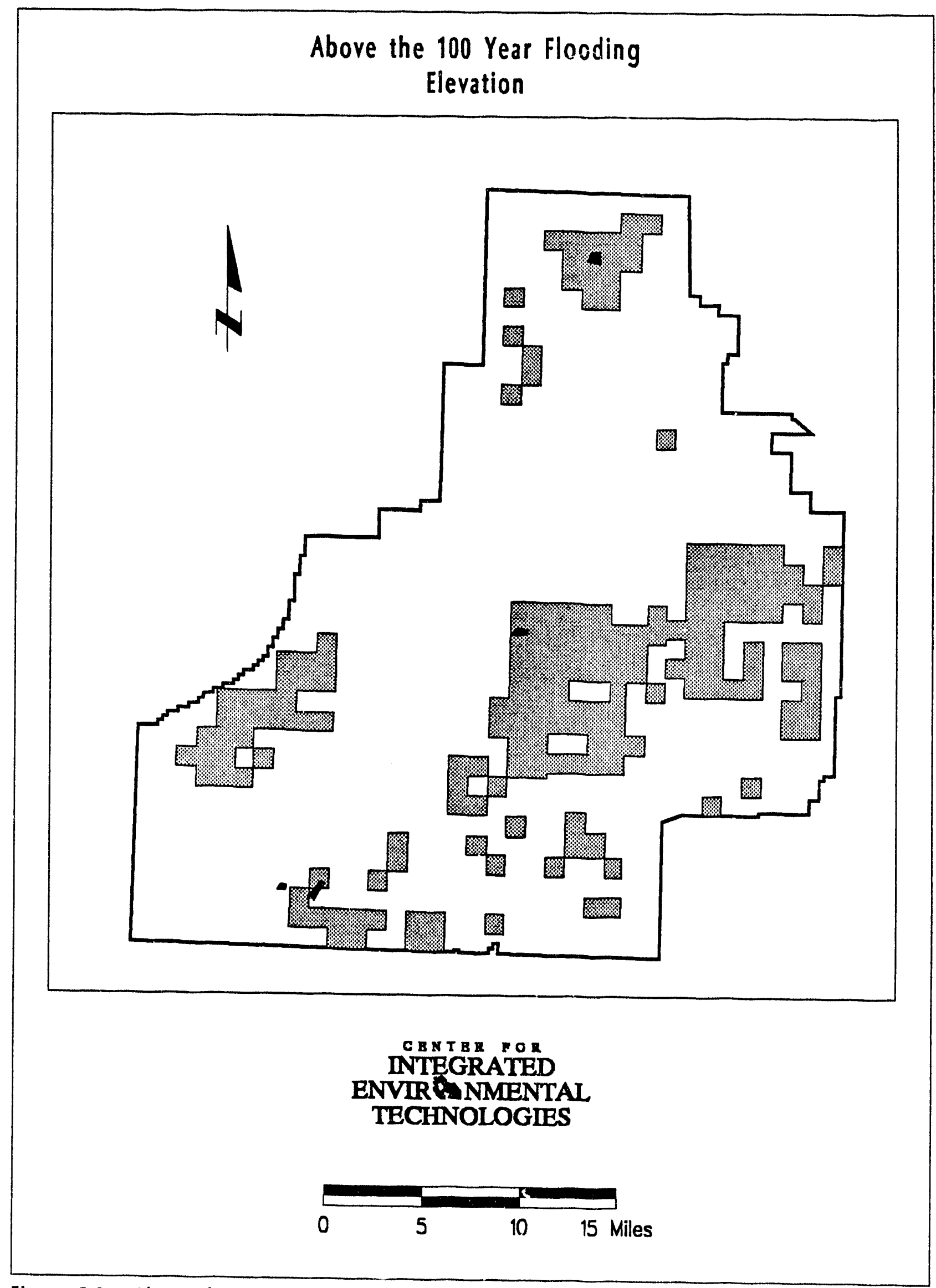

Figure 3-2. Above the 100 Year Flooding Elevation 


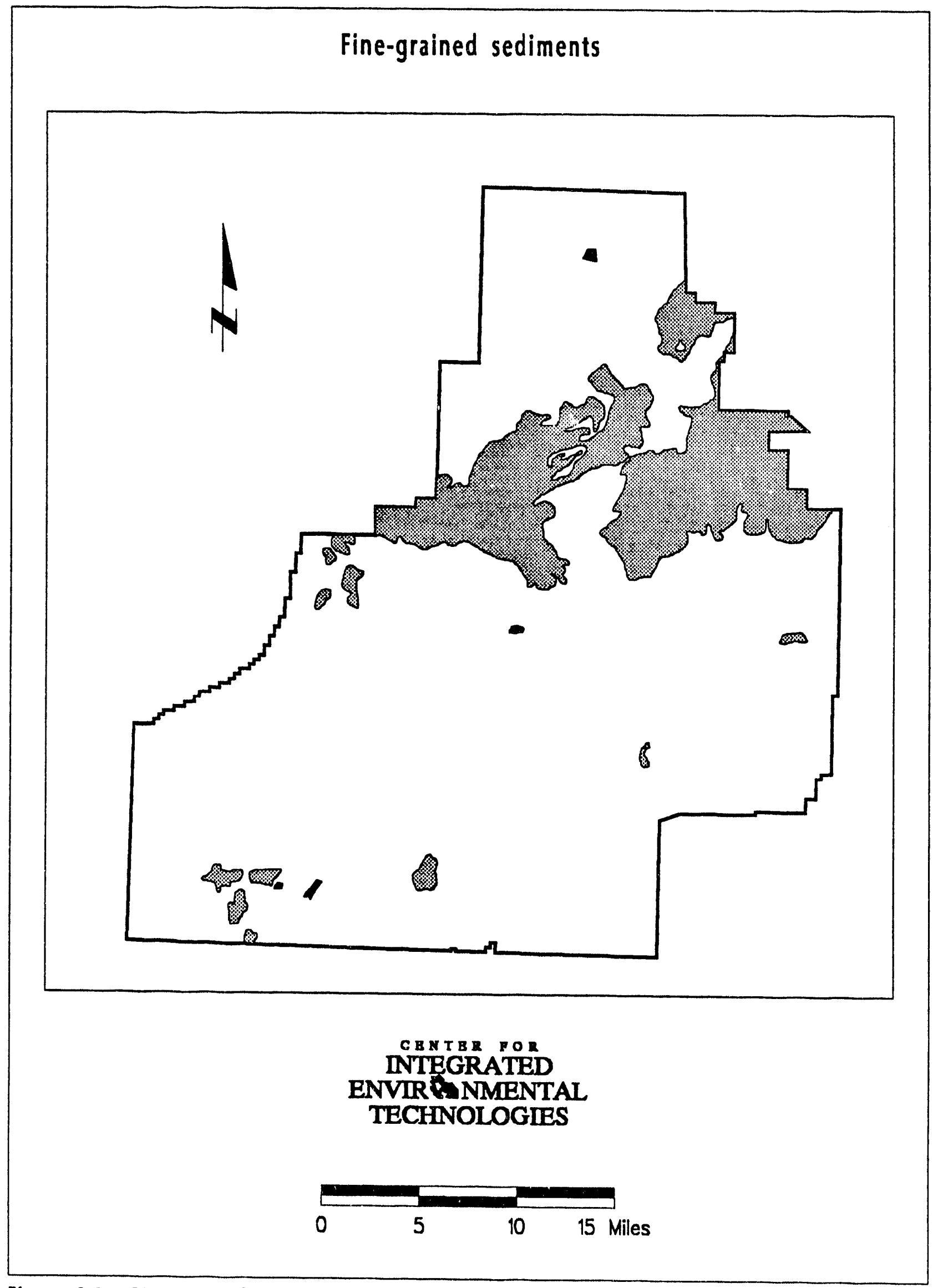

Figure 3-3. Fine-grained Sediments 


\subsubsection{Minimum potential for airborne contamination of the public}

The areas on the INEL with minimum potential for airborne contamination to the public (Figure 3-4) are areas where the prevailing winds are least likely to blow plumes into inhabited areas such as Atomic City or the Mud Lake-Terreton areas.

\subsubsection{FFA/CO sites and Environmentally Controlled Areas}

The Federal Facility Agreement and Tonsent Order (FFA/CO) sites (Figure 3-5) are waste management units identified under the previous Consent Order and Compliance Agreement (COCA), which was superseded by the FFA/CO. The environmentally controlled areas include a buffer area to protect the sites from disturbance.

\subsubsection{Within 1 mile of Category I facilities and/or existing/proposed reactors}

The areas shown in Figure 3-6 are one mile buffers around the centers of any Category I facility, defined by DOE Order 5480.23 as any nuclear facility whose hazard analysis shows the potential for significant offsite consequences. In addition, the buffered locations of existing or proposed reactors are included.

\subsubsection{Wind corridors of existing facilities}

Using the prevailing wind direction data for the INEL, the wind corridors were used to define where plumes from existing facilities are likely to impact new facilities, and vice versa (Figure 3-7).

\subsubsection{Most vulnerable to lava flows}

These areas (Figure 3-8) are most subject to lava inundation based on eruption of lava fields of reasonable size from the areas where northwest trending volcanic rift zones intersect the Axial Volcanic Zone of the INEL. It has been estimated that the probability of such an occurrence impacting the south-central part of the INEL is about once in 100,000 years.

\subsubsection{Most vulnerable to volcanic fissuring}

The areas shown in Figure 3-9 represent regions of the INEL with the highest potential for ground deformation associated with subsurface magma movement (fissuring, minor faulting, and uplift) near volcanic vents along volcanic rift zones. 


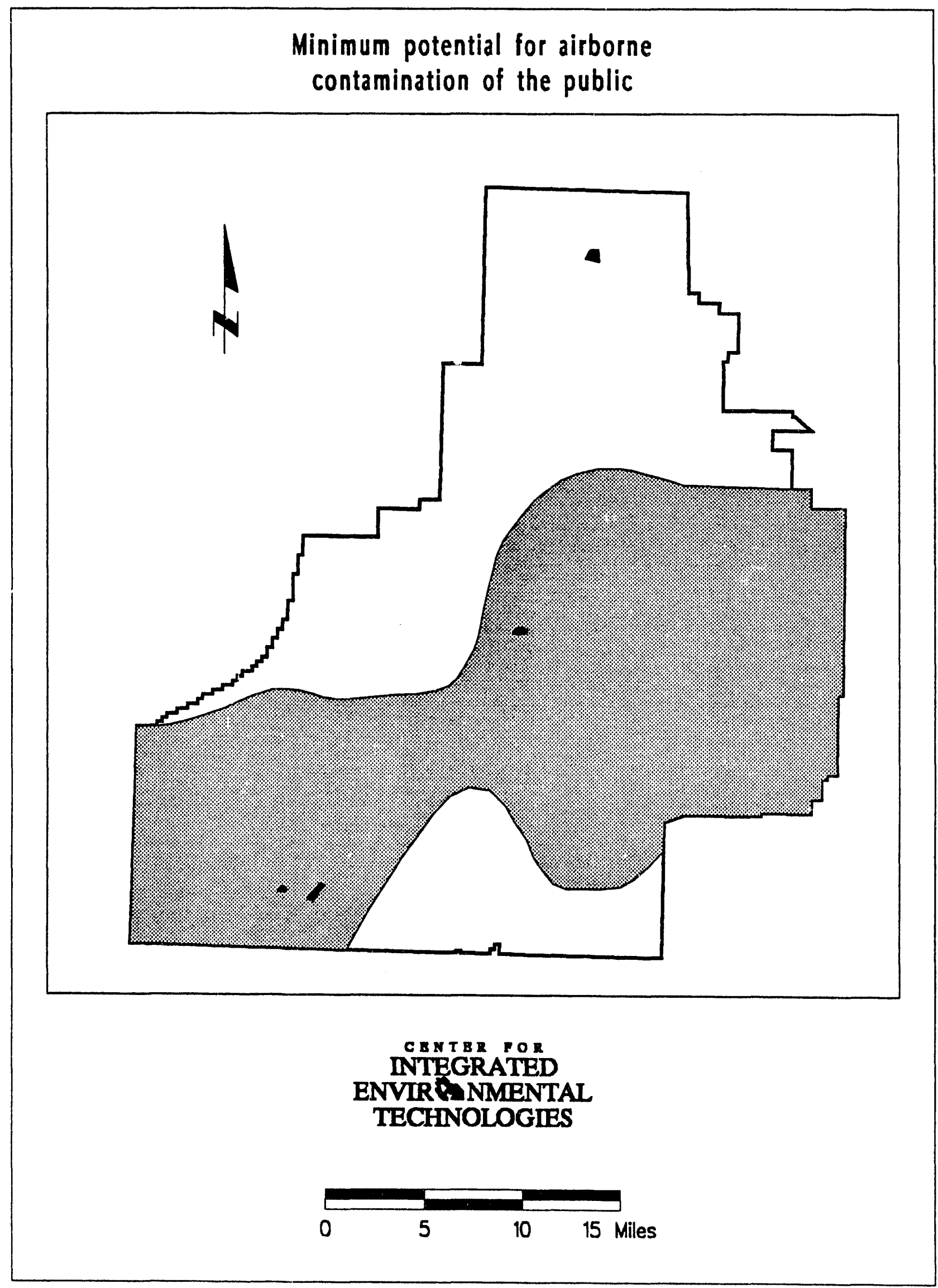

Figure 3-4. Minimum potential for airborne contamination to the public 


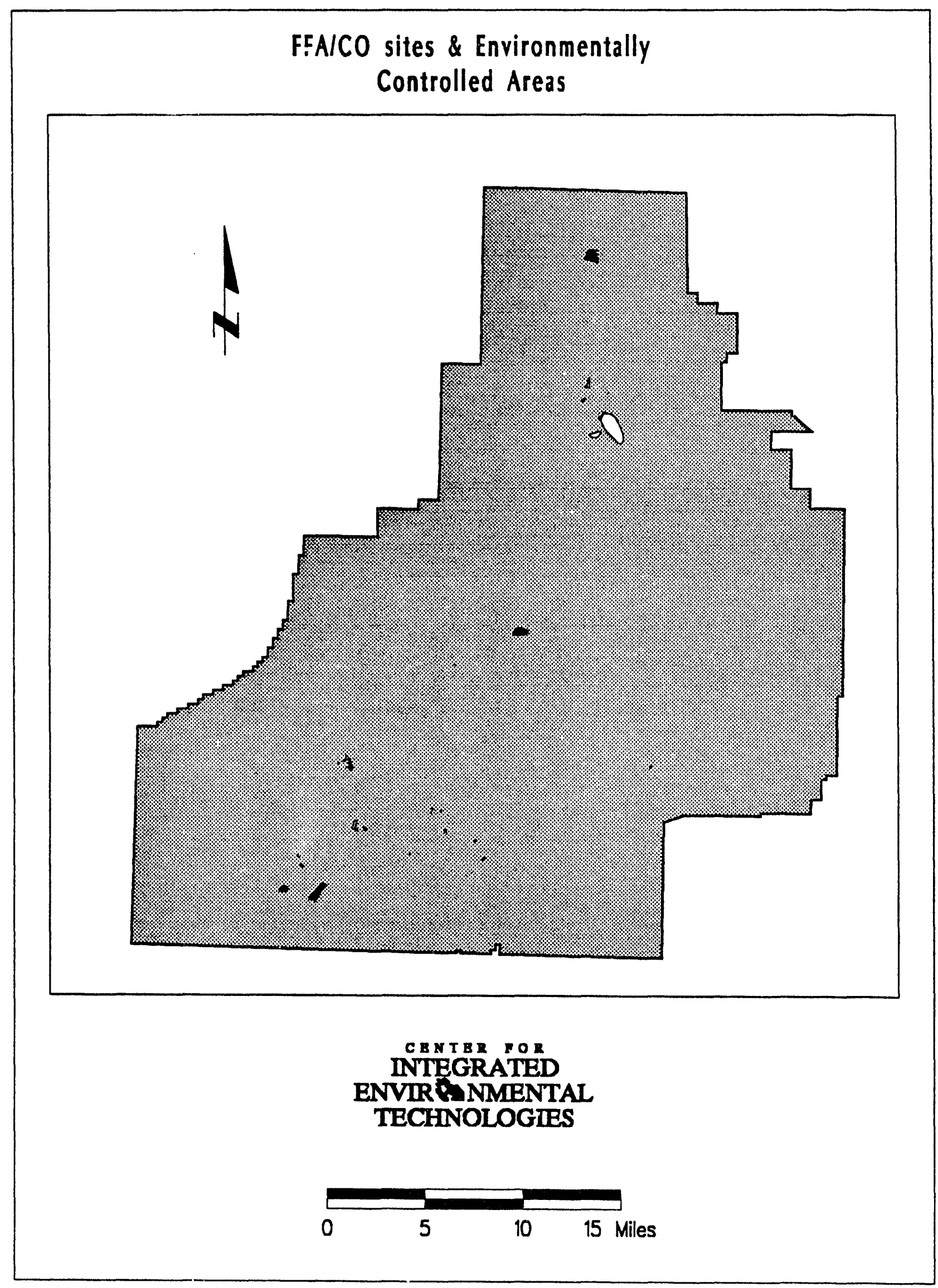

Figure 3-5. FFA/CO sites \& Environmentally Controlled Areas 


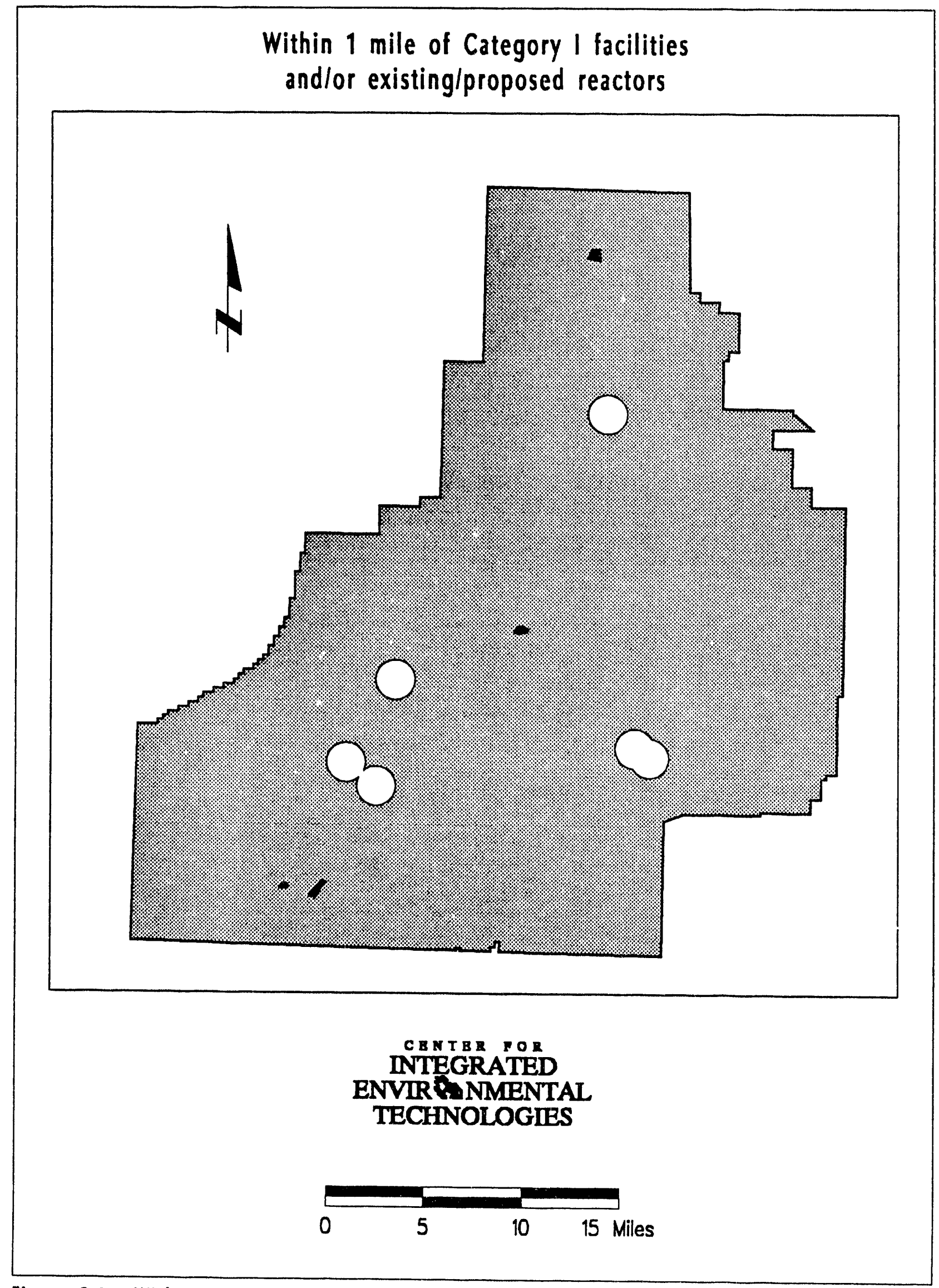

Figure 3-6. Within 1 mile of Category I facilities and/or existing/proposed reactors 


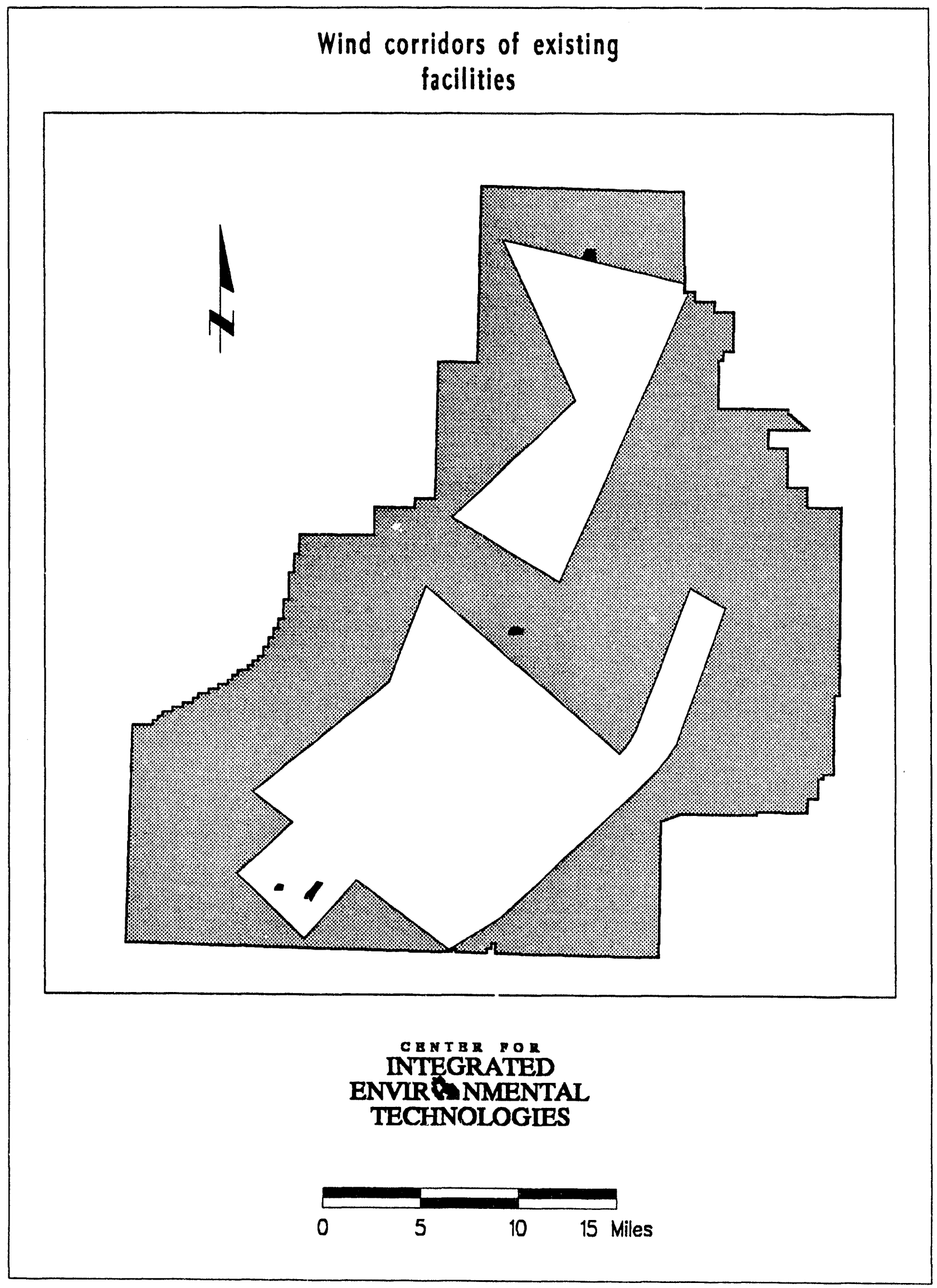

Figure 3-7. Wind corridors of existing facilities 


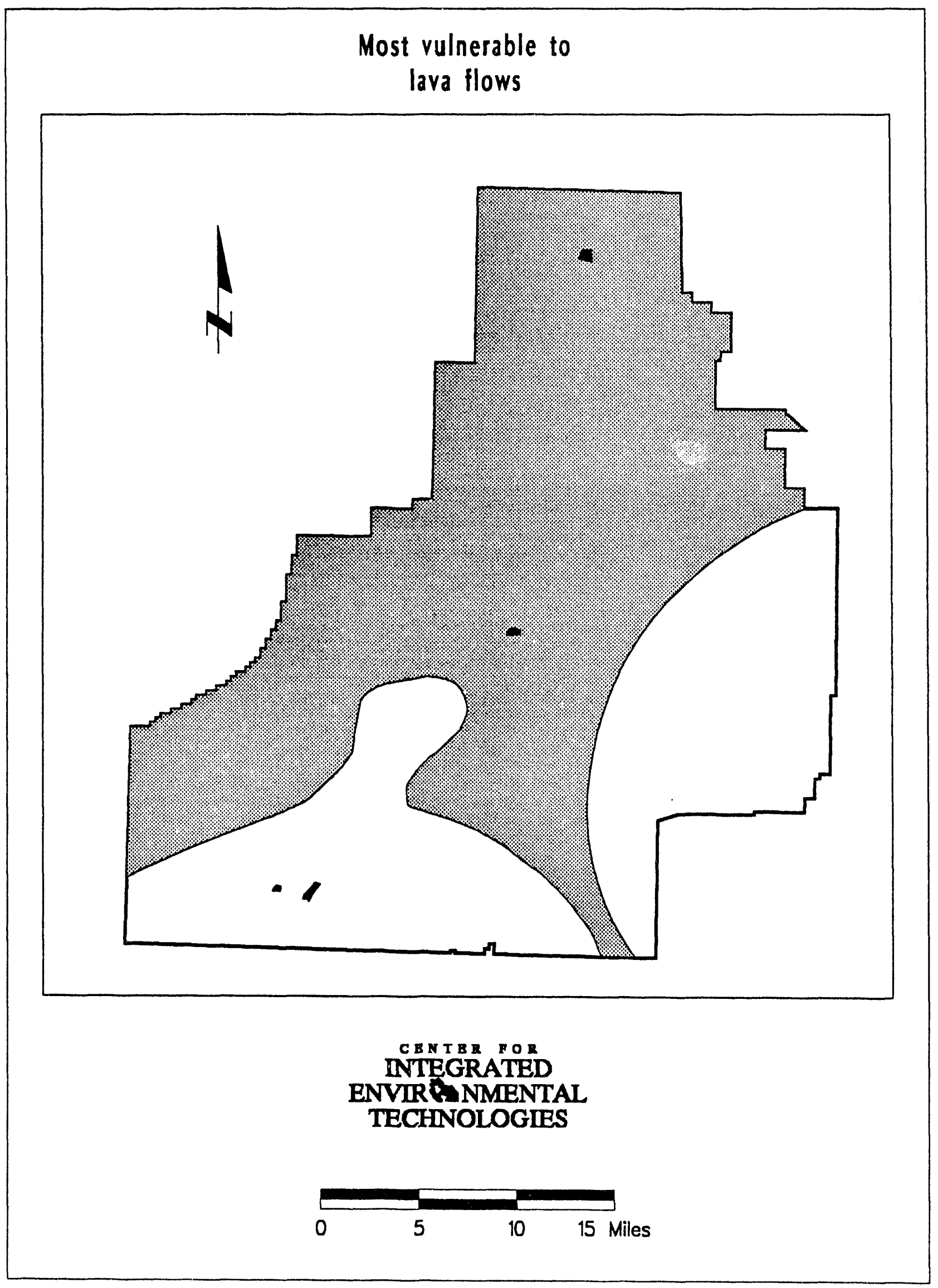

Figure 3-8. Most vulnerable to lava flows 


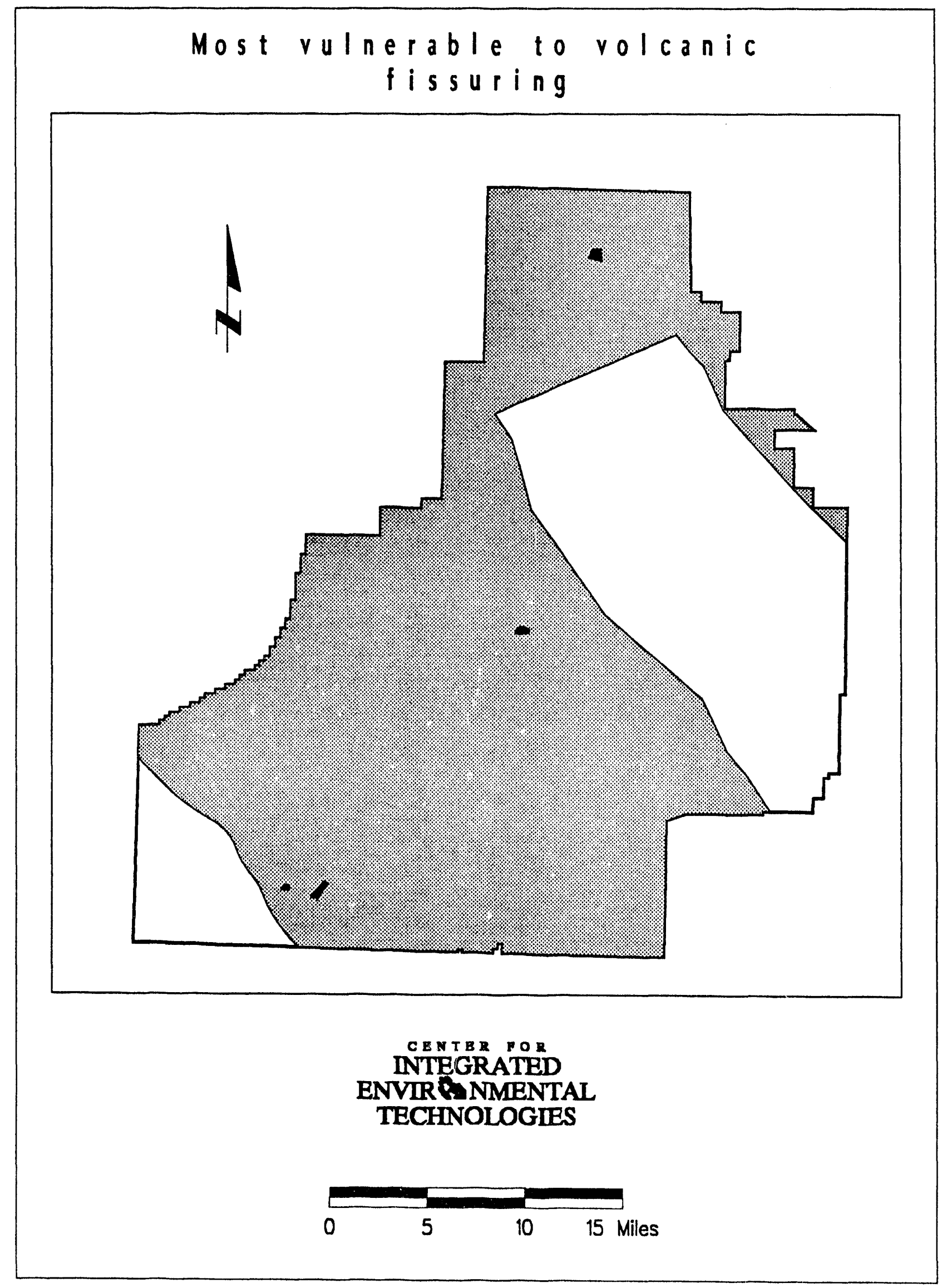

Figure 3-9. Most vulnerable to volcanic fissuring 


\subsubsection{Within One Mile of a Capable Fault}

The region in Figure 3-10 was determined considering faults with one or more of the following characteristics:

a) movement within the past 35,000 years or recurrent movement within the past 500,000 years,

b) instrument-determined macroseismicity demonstrating a direct relationship with the fault, or

c) structural relationship of the fault to another capable fault.

\subsubsection{Reserved for other INEL projects}

The areas that have been selected for other proposed projects at the INEL are shown in Figure $3-11$.

\subsubsection{Not above aquifer}

The area in Figure 3-12 is based on a U. S. Environmental Protection Agency (EPA) document showing this boundary based on the statement:

"Generally, the aquifer boundary is the contact between Quaternary sedimentary and volcanic rocks and the surrounding Tertiary and older rocks."

\subsection{Description of the Analysis}

\subsubsection{All Criteria}

The initial analysis was made by considering all of the criteria as having equal importance in determining the areas of the INEL that would best satisfy the requirements. The analysis was done after using the Arc/Info ${ }^{\infty}$ GIS to mathematically combine all of the individual criteria into Figure 3-13.

Each of the individual areas (polygons) shown in Figure 3-13 has associated with it a set of attributes. This set of attributes defines whether or not each individual criterion is satisfied within that polygon.

Using these attributes as the input data, a model was developed to determine another attribute for each polygon. That attribute is a summary of how many of the criteria are met within the polygon. Later analyses with the model also considered the relative importance of different criteria. Statistical analysis of this summary attribute, for all polygons combined, was used to determine those areas of the INEL that best met the criteria.

These results, for all criteria assumed to be of equal importance, are reported in Table 3-1. 


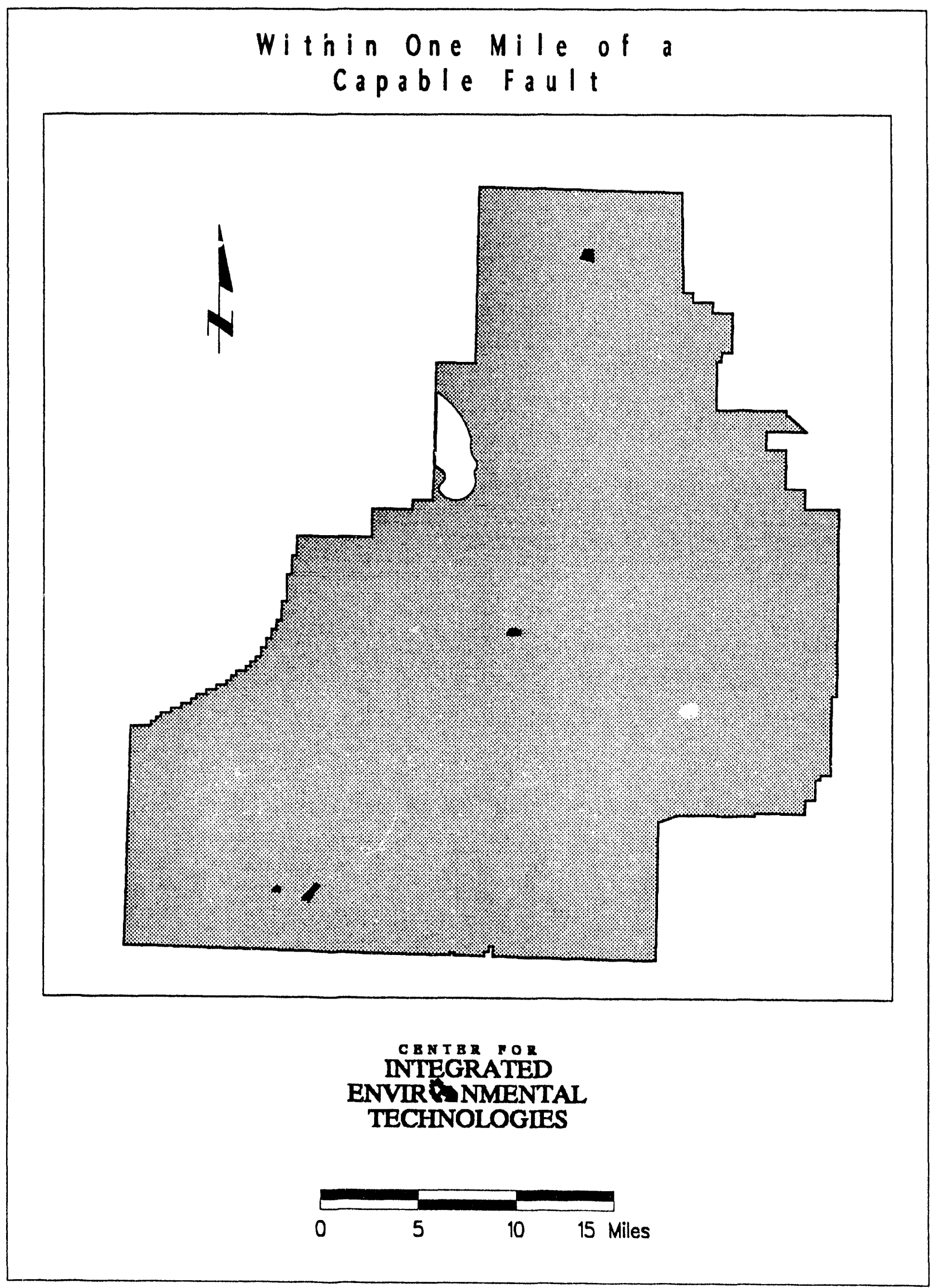

Figure 3-10. Within 1 mile of a capable fault 


\section{Reserved for other INEL \\ projects}

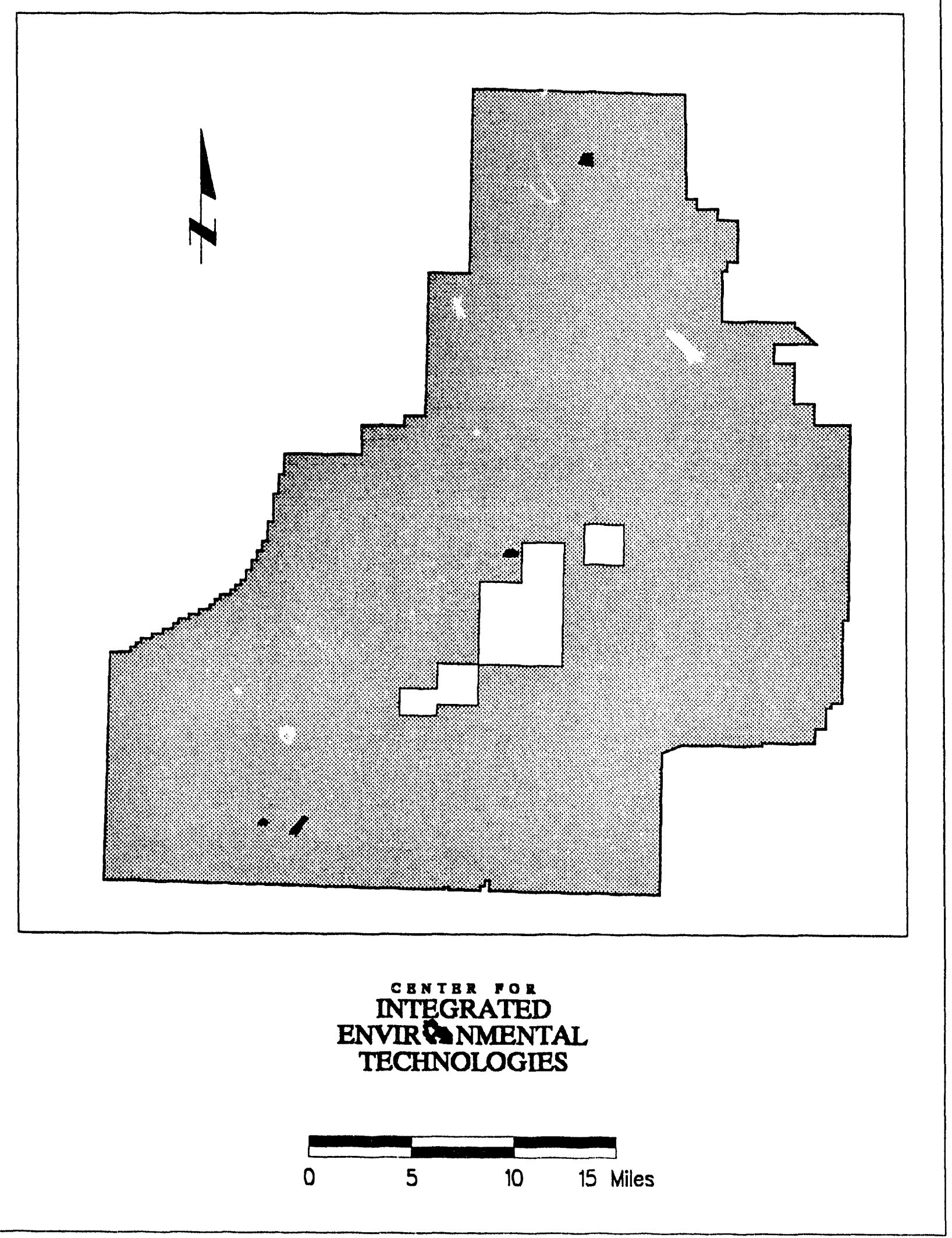

Figure 3-11. Reserved for other INEL projects 


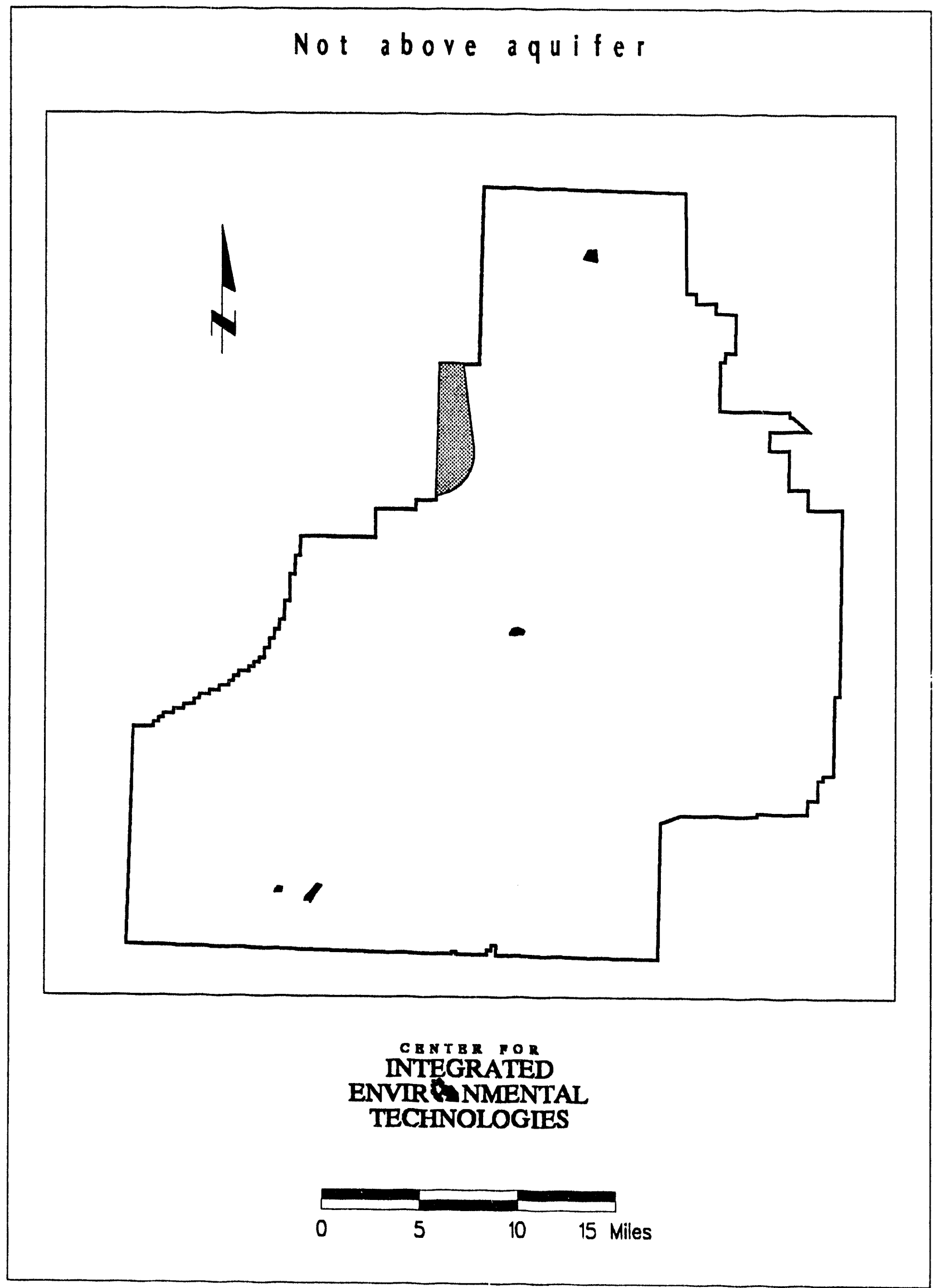

Figure 3-12. Not above aquifer 


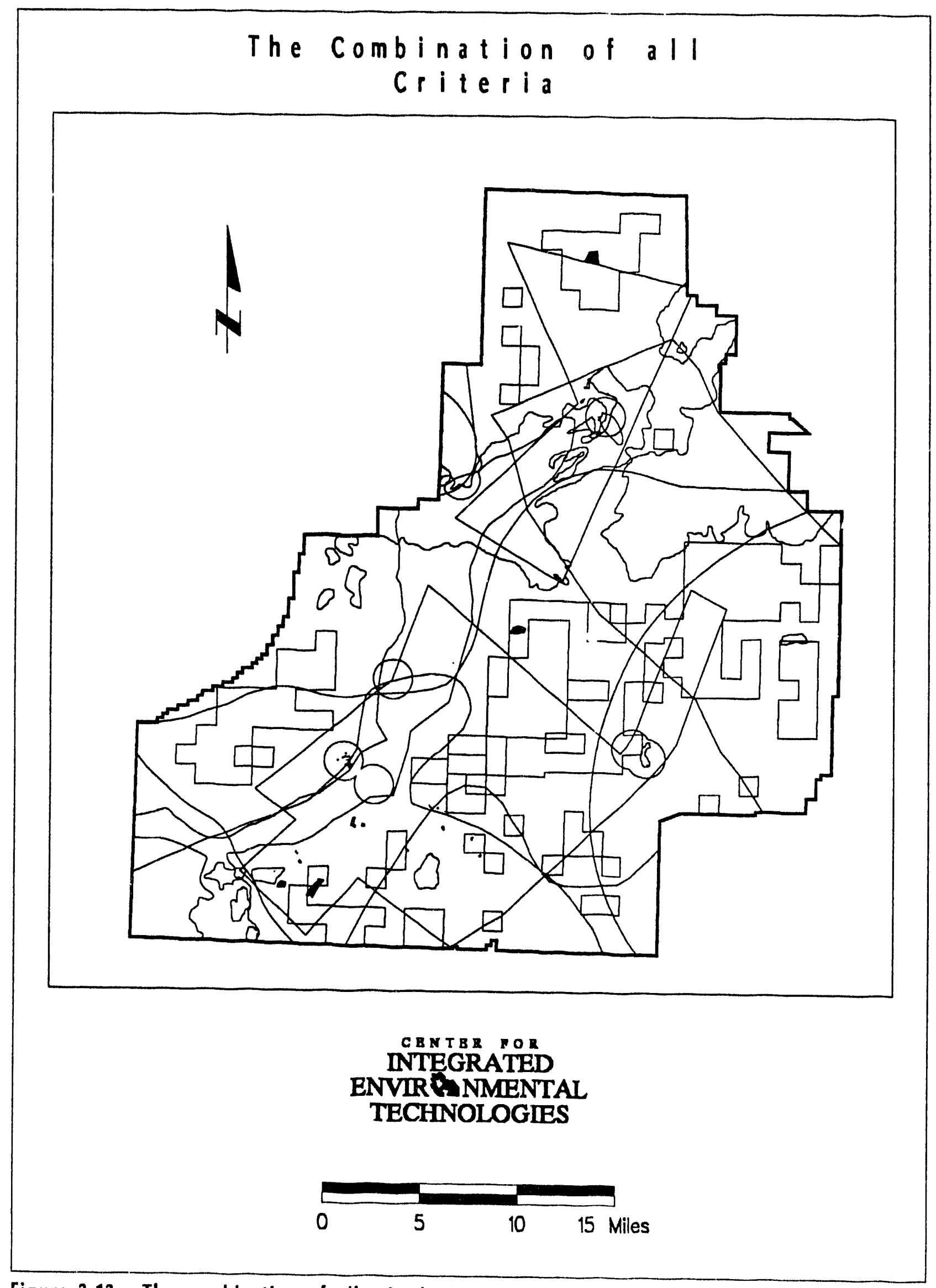

Figure 3-13. The combination of all criteria 
Table 3-1. Summary of "All Criteria" analysis

\begin{tabular}{ccc} 
Number of criteria met & Number of polygons & Area (acres) \\
4 & 3 & 774 \\
5 & 41 & 4,955 \\
6 & 69 & 54,996 \\
7 & 79 & 170,064 \\
8 & 94 & 212,545 \\
9 & 60 & 102,756 \\
10 & 10 & 24,833 \\
& & \\
Totals & 356 & 570,923 \\
\hline
\end{tabular}

A review of the Table 3-1 statistics shows that there are 10 polygons in Figure 3-13 that meet 10 of the 12 criteria, with an area of 24,833 acres, 60 polygons that meet 9 of the criteria, and 94 polygons that meet 8 of the criteria. These areas are shown in Figures 3-14, 3-15, and 3-16.

\subsubsection{Unsatisfied Criteria.}

Once the GIS analysis was complete, and the areas best meeting the criteria reviewed, the neyt analysis addressed the question of what criteria were not met by those 10 polygons that satisfied 100 the 12 criteria.

In 9 of the 10 polygons, the criterion "Not above aquifer" was not satisfied. Five polygons did not meet the criterion of "Fine-grained sediments", 4 did not satisfy "Above the 100 Year Flooding Elevation", 1 was in an area subject to volcanic fissuring, and 1 was not in the area of minimum potential for airborne contamination to the public.

\subsubsection{Selected Criteria}

As indicated in the preliminary siting report, four of the criteria were identified as "must" criteria that had to be satisfied.

The summary 0 : "all criteria" indicated that the maximum number of criteria met was 10 . Therefore, by revising the model to emphasize the selected "must' criteria with a value of 10 , we are assured mathematically that those polygons which meet the "must" criteria will always better meet all criteria than some polygon or polygons that might meet 10 individual (non-"must') criteria. Furthermore, since 10 criteria was the maximum number met, setting the "must" criteria value to something more than 


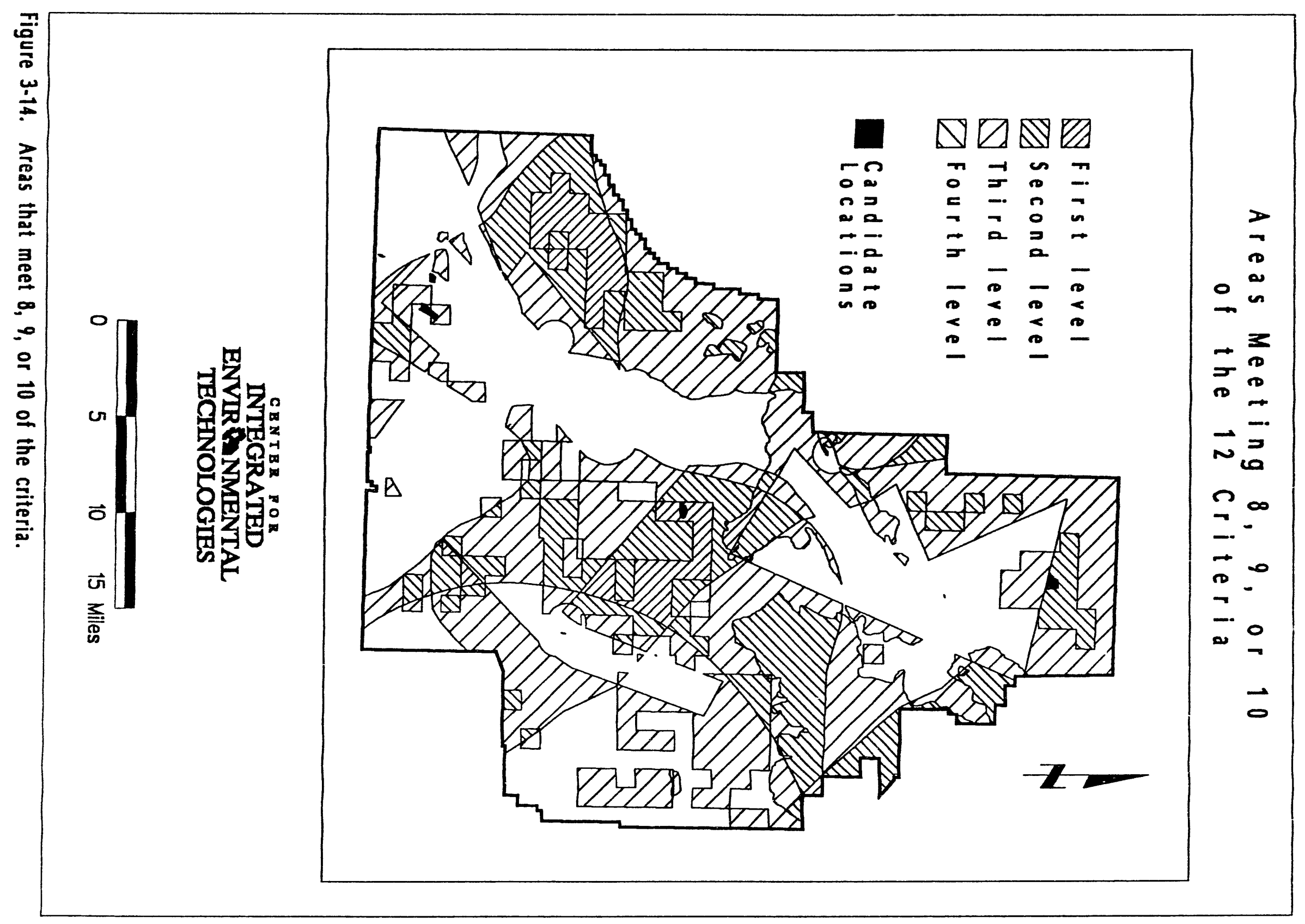




\section{Areas Meeting 9 or 10 of the $12 \mathrm{Criteria}$}
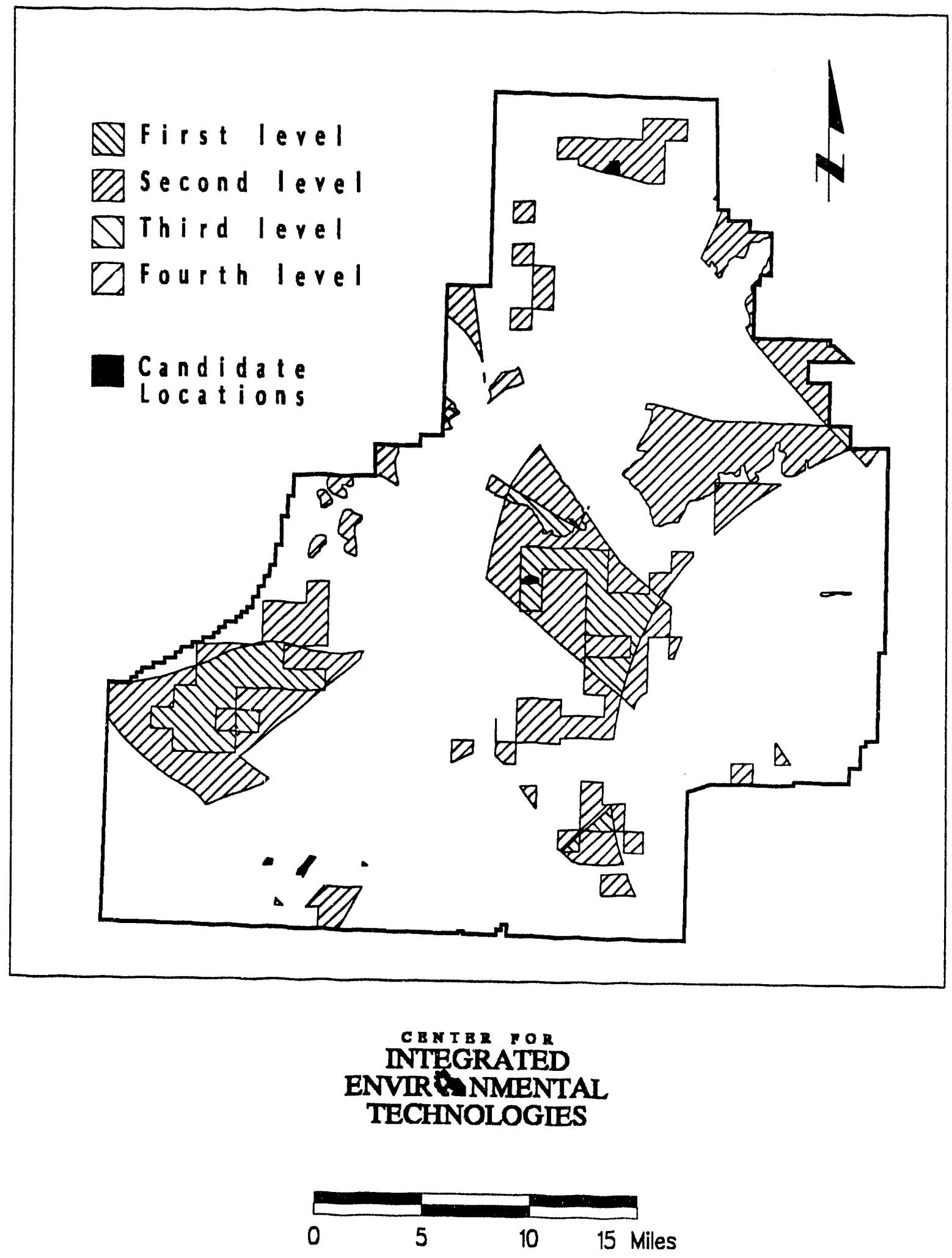

Figure 3-15. Areas that meet 9 or 10 of the criteria. 


\section{Areas Meeting 10 \\ of the 12 Criteria}

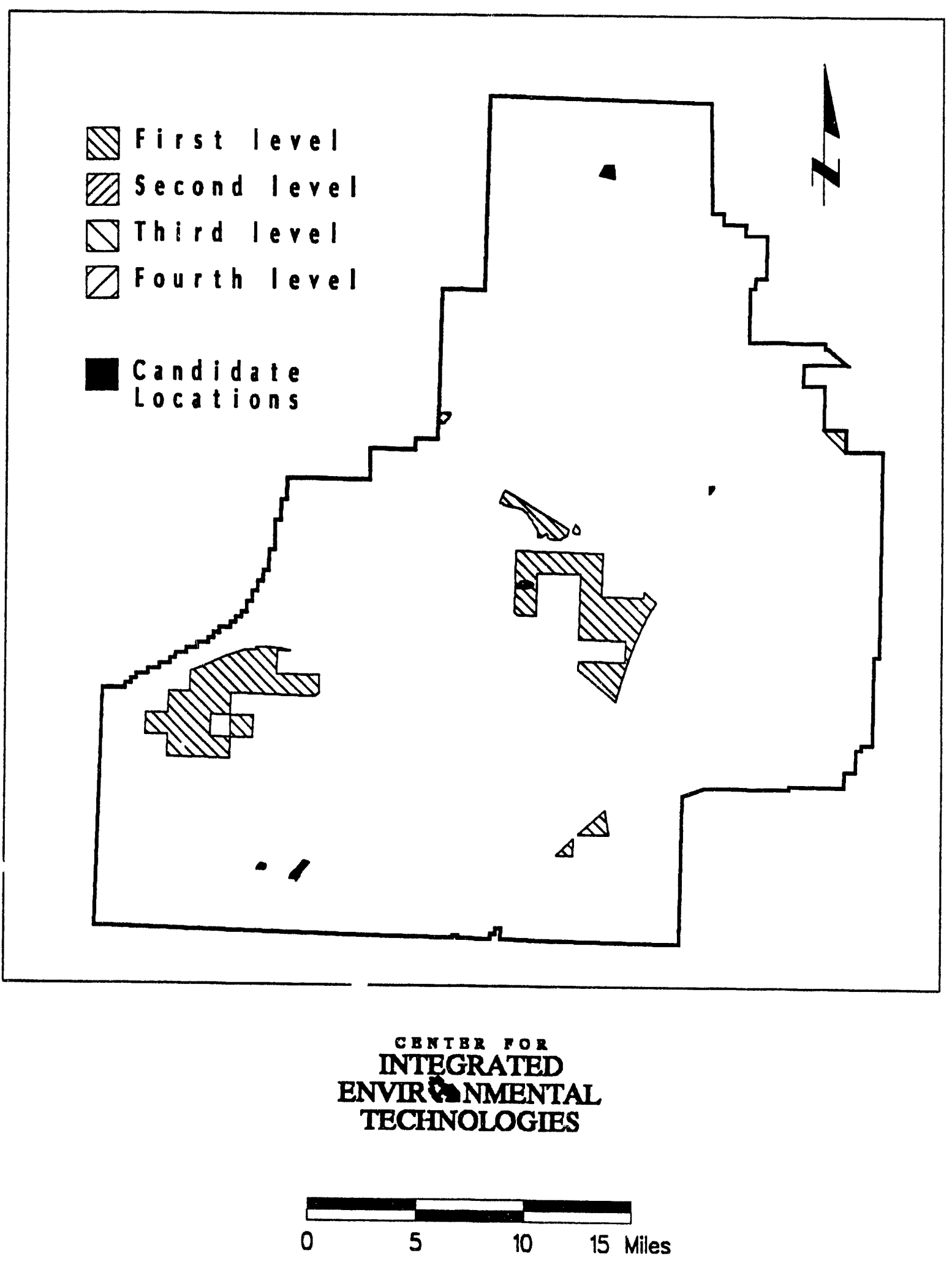

Figure 3-16. Areas that meet 10 of the criteria. 
10 (such as 20 or 100) will have no additional impact on the results, and shows that the "value" is numerically meaningless except to distinguish the "must" criteria.

The statistical summary of the selected criteria is Table 3-2. A review of these data shows that the best polygons were at selection levels $46,45,44$, and 43 . Those polygons which were at level 46 were the polygons that satisfied 10 criteria, the 4 "must" criteria (4 times 10, or 40), and the other 6 criteria (6 times 1, or 6). Likewise, the others satisfied all 4 "must" criteria, but fewer of the other criteria. Figure 3-17 shows these areas of the INEL that meet the selected criteria.

Table 3-2. Summary of Selected "Must" Criteria Analysis

Selection Level

13

14

15

23

24

25

26

27

33

34

35

36

37

43

44

45

46

Totals
Number of polygons

3

19

15

22

32

25

4

1

22

46

59

28

4

8

31

31

6

356
Area (acres)

774

3,245

560

1,710

31,024

21,847

6,926

91

23,413

139,606

157,132

62,192

1,929

8,612

48,488

40,474

22,904 


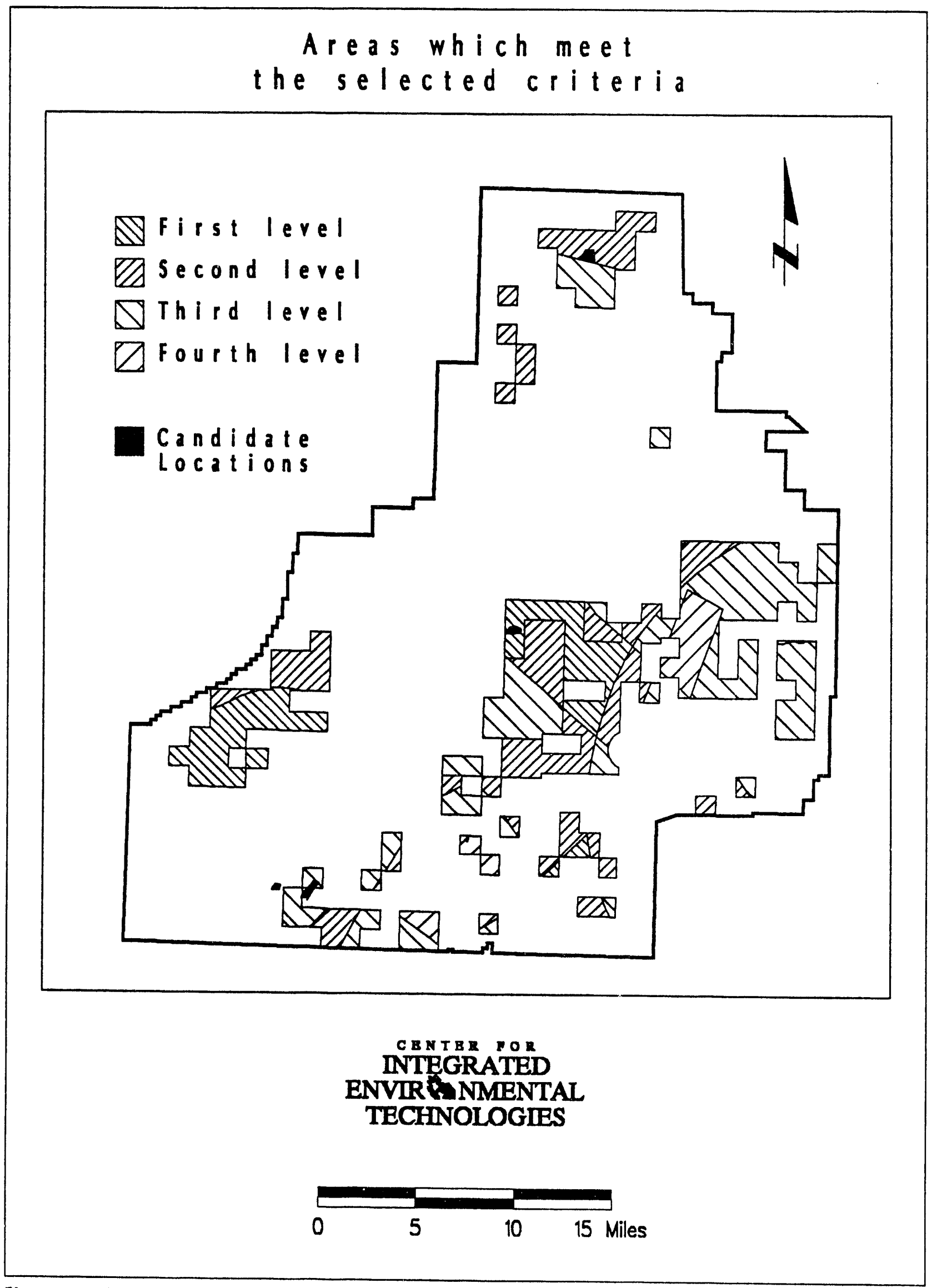

Figure 3-17. Areas which meet the selected criteria. 


\subsection{Evaluation of Results}

As can be seen from Figures 3-10 and 3-12, the criterion "Within 1 mile of a capable fault" and the criterion "Not above aquifer" are almost totally mutually exclusive. Perhaps these criteria should be reviewed in light of this conflict.

The criterion "Not above aquifer" does not play a significant role in the siting decision-making process (See Section 3.2.1.1). If this criterion is of significant importance, revisions to the siting analyses should be made.

Based on the 12 criteria defined, and selecting 4 of them as "must" criteria, it can be seen from Figure 3-17 that Candidate Location \#3 best meets the criteria, followed by Candidate Location \#5, then Candidate Locations $\# 1$ and \#9. 


\section{ADDITIONAL ANALYSES}

In addition to the 12 criteria used for the siting study, there were 4 other criteria that could reasonably be considered as relatively important to the study.

The first criterion is consideration of areas south of the U. S. Highways 20 and 26 , so that formal compliance with U. S. Department of Transportation (DOT) regulations dictating the use of certified containers in shipping waste is not required. This area is shown in Figure 4-1. The shaded areas indicate desirable locations. Figure 4-2 shows the selected criteria combined with the "South of the Highways" criterion.

Another criterion of interest is to consider the distance from the Radioactive Waste Management Complex (RWMC). As an example for demonstration purposes, a proximity factor was designed. Figure 4-3 represents this proximity factor, considering locations within 1 mile of RWMC as significant as the "must" criteria, locations from 1 to 5 miles away as half as significant, those 5 to 10 miles away as similar to the other criteria (non-"must'), and locations more than 10 miles away as of no additional significance. Figure 4-4 represents the combination of the selected criteria and the distance from RWMC.

Two other criteria that were considered were to prohibit selection of locations within 1 mile of the public highways passing through the INEL and within 2 miles of the INEL boundary. These are shown in Figures 4-5 and 4-6. The shaded areas indicate undesirable locations.

The combination of all the criteria in the study, including selected criteria, south of the highways, the distance from RWMC, and the road and boundary buffers, results in Figure 4-7. These areas are the ones on the INEL that best satisfy all the mentioned criteria. Since the Fourth Level areas shown are located at RWMC, and therefore not available for consideration, Figure 4-8 presents the results showing only the top three levels. 


\section{South of the Highways}

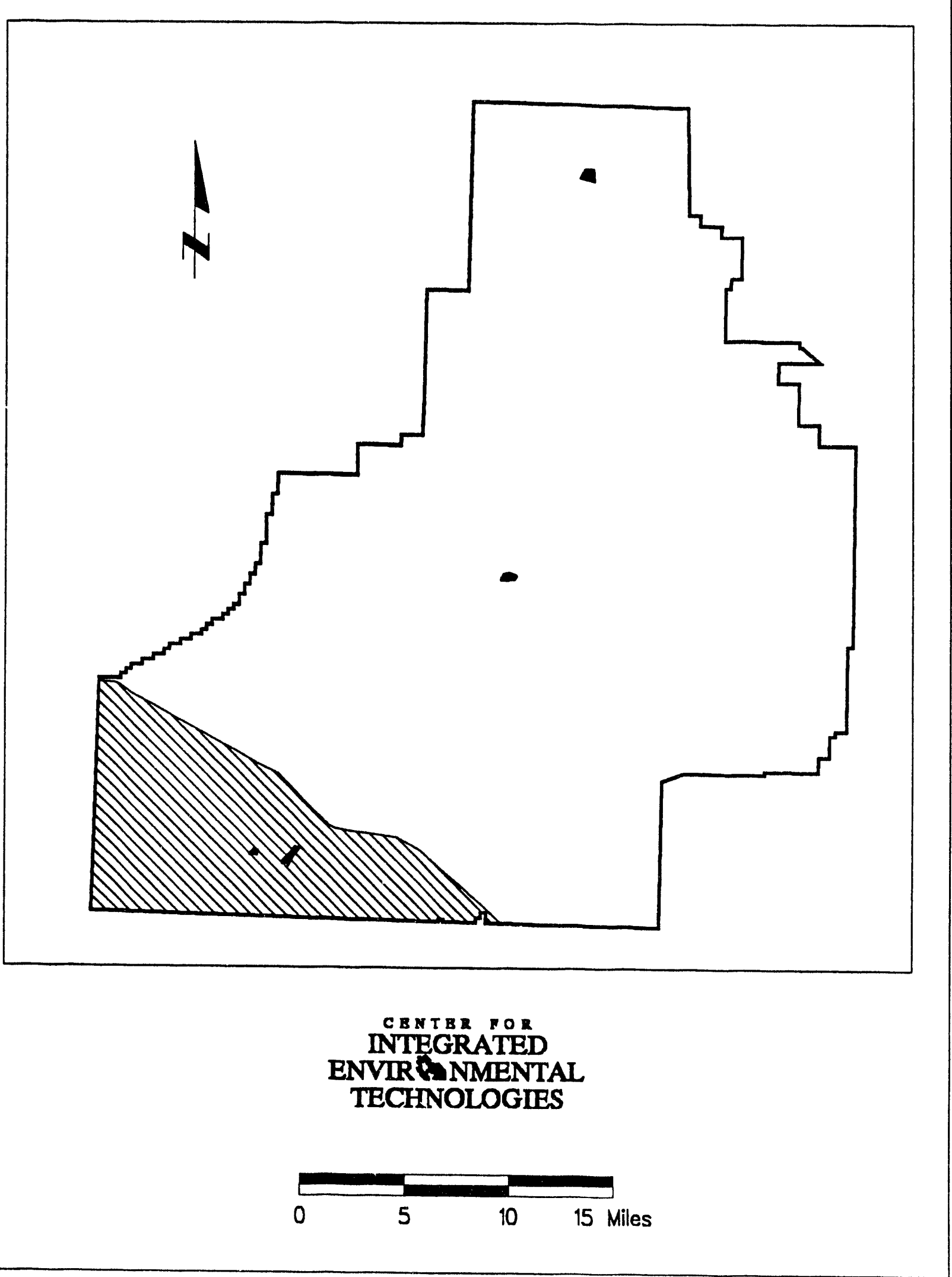

Figure 4-1. South of the highways. 


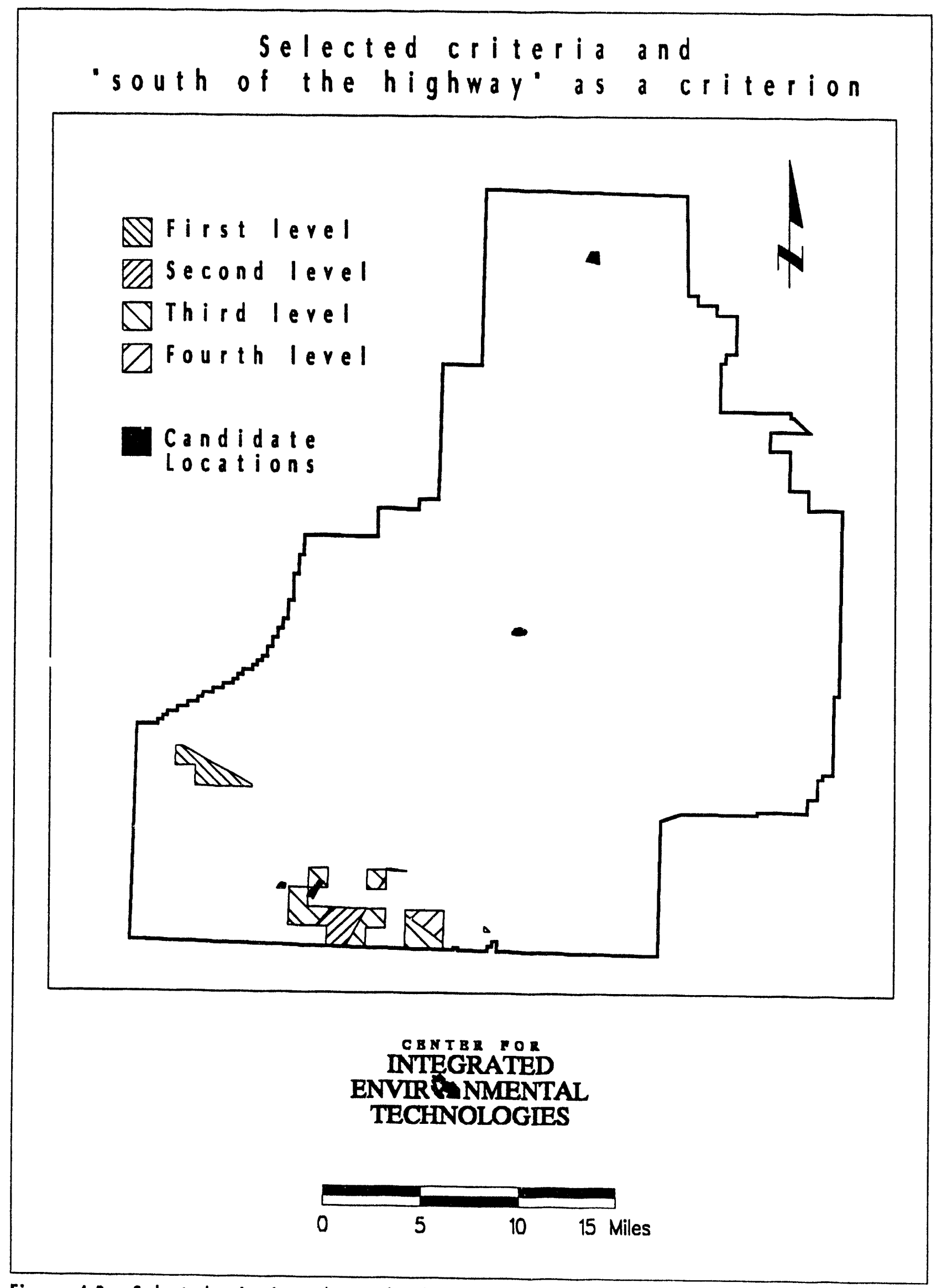

Figure 4-2. Selected criteria and 'south of the highway" as a criterion 


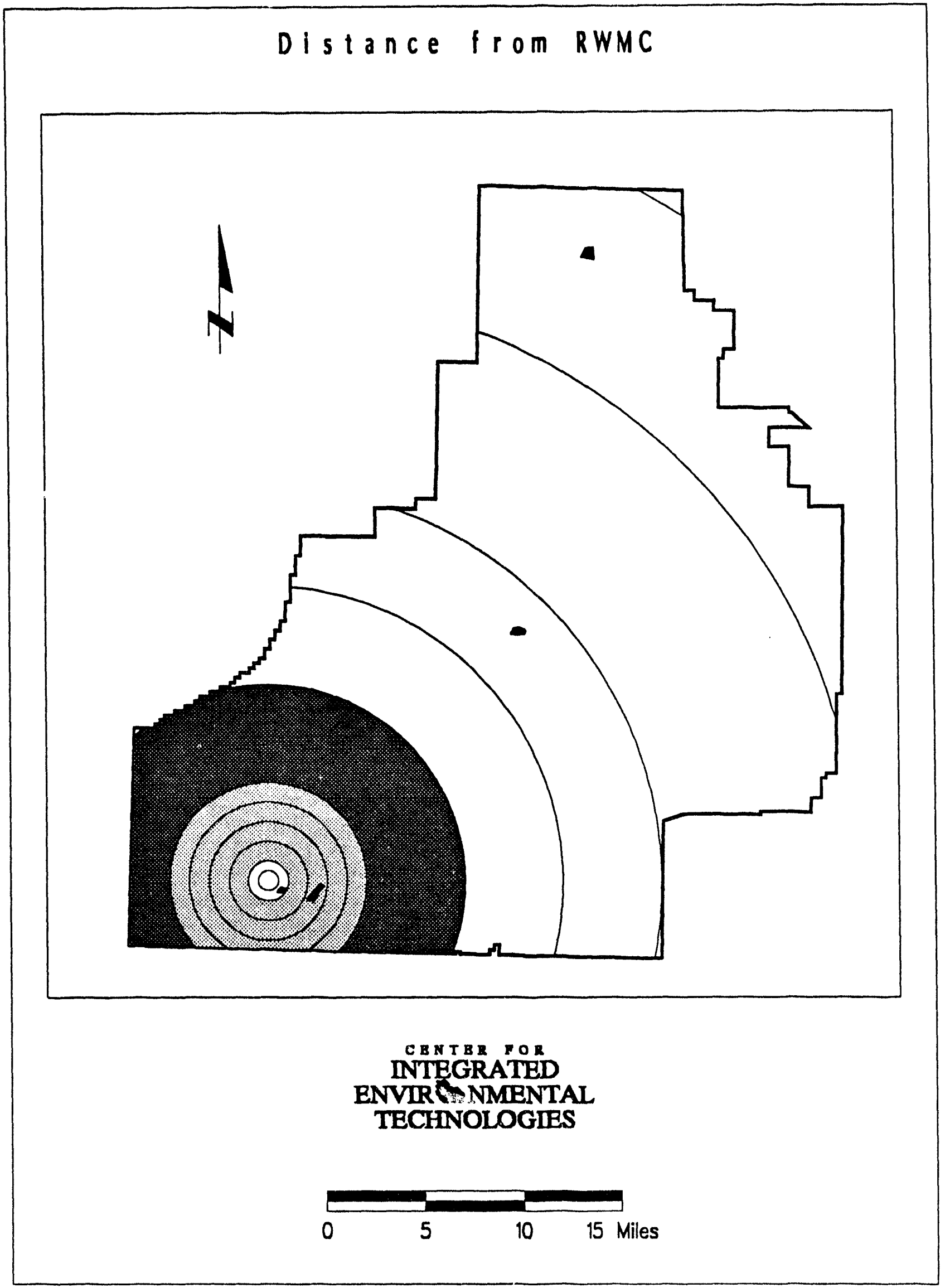

Figure 4-3. Distance from RWMC 


$$
\begin{aligned}
& \text { Selected criteria and } \\
& \text { distance from RWMC }
\end{aligned}
$$

Pirst level

Decond level

$\triangle$ Third level

$\square$ fourth level

Candidate

Locations
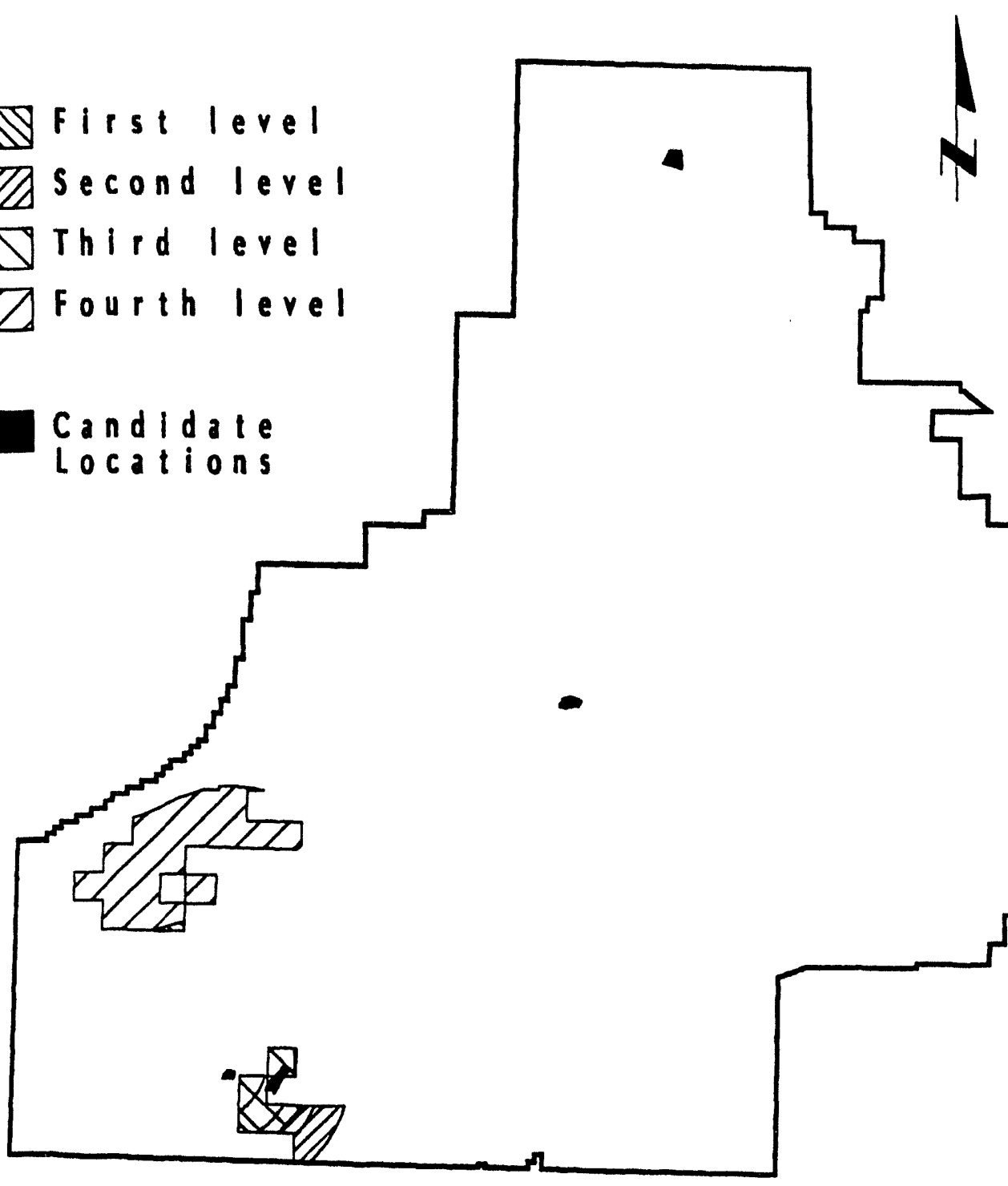

CBNTBR $10 R$

INTEGRATED

ENVIR WNMEI TAL

TECHNOLOGCIES

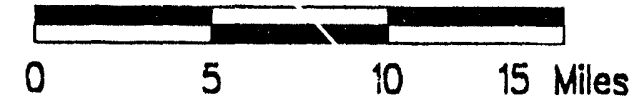

Figure 4-4. Selected criteria and distance from RWMC. 


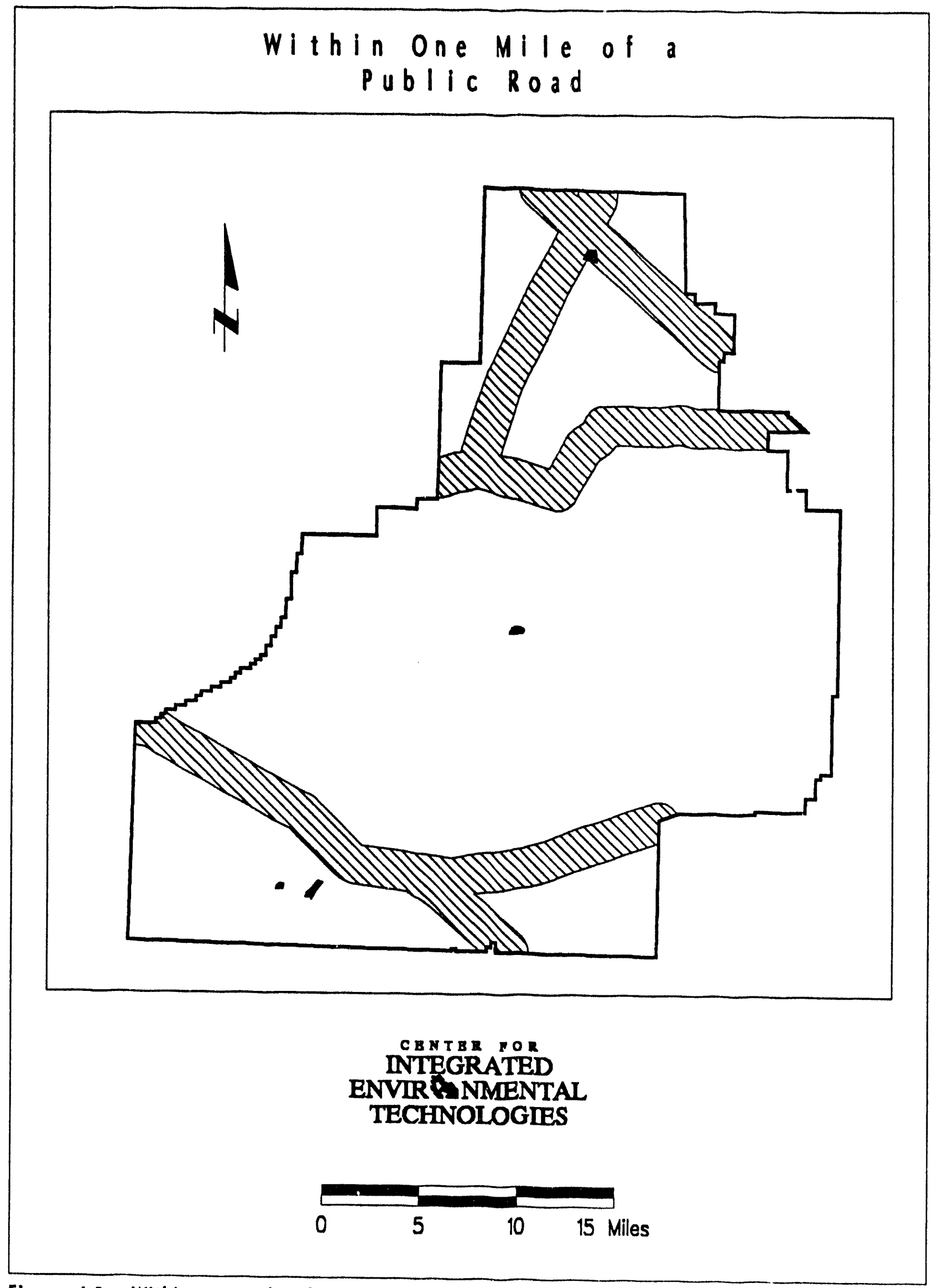

Figure 4-5. Within one mile of a public road. 


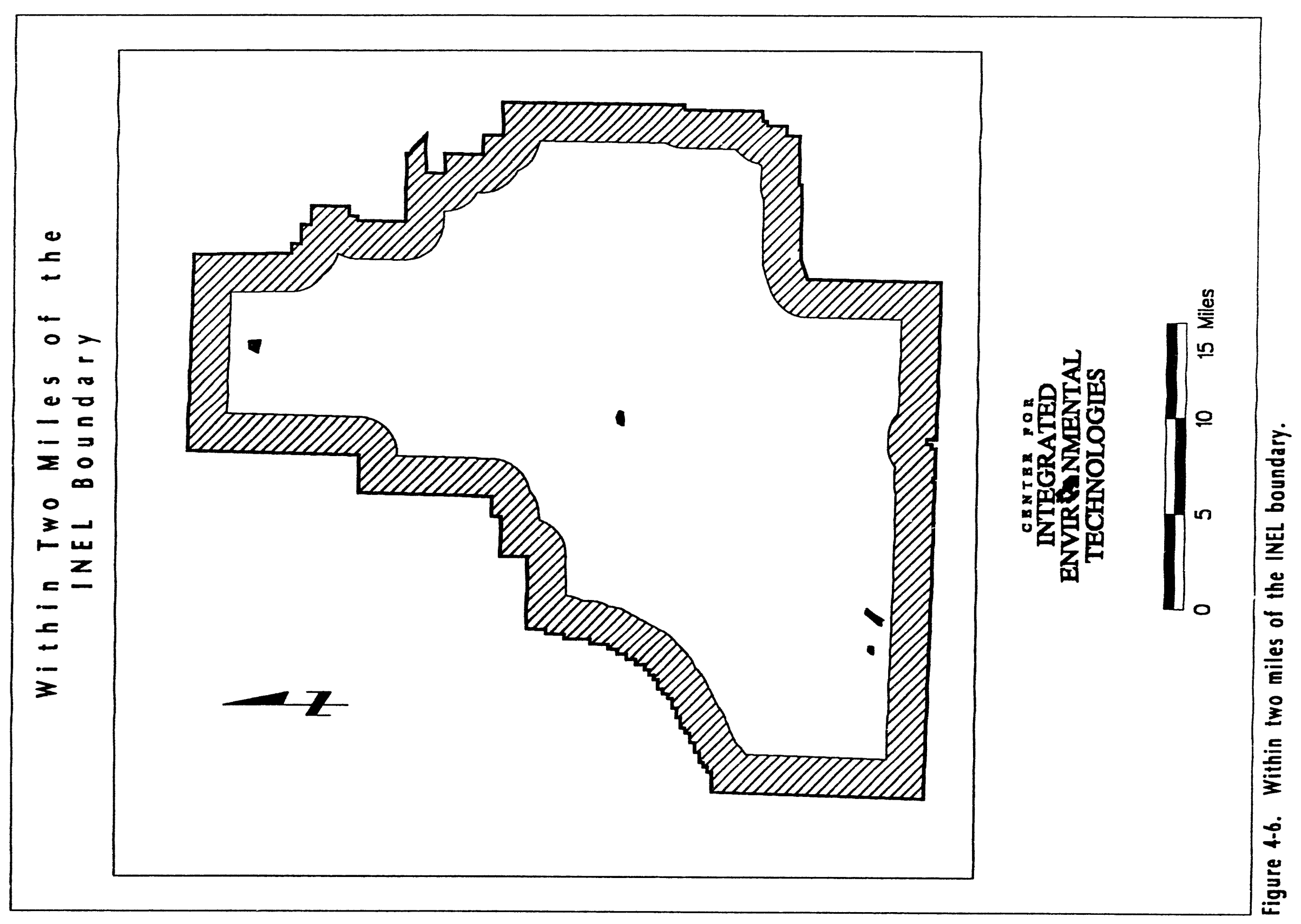


Areas Best Meeting All Criteria (top 4 levels)

$\mathbb{M i n s t}$ level

QSecond level

$\Delta$ Third level

$\square$ fouth level

Candidate

Locations

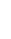

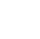

TECHNOLOGIES

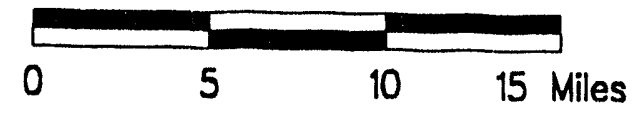

Figure 4-7. Areas best meeting all criteria (top 4 levels) 


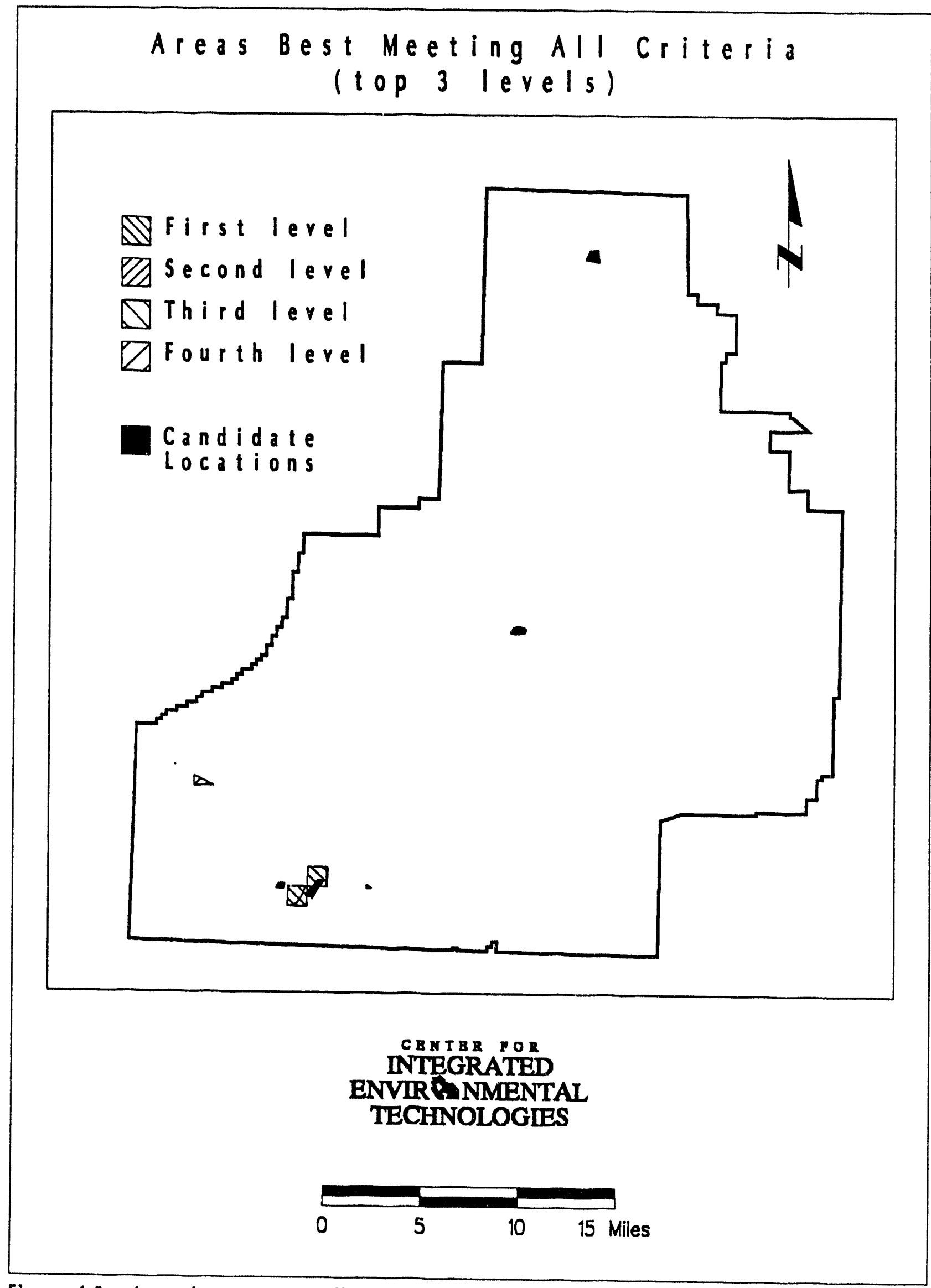

Figure 4-8. Areas best meeting all criteria (top 3 levels) 


\section{CONCLUSIONS}

This GIS analysis of the siting criteria for the IWPF and MLLWTF provides a logical, repeatable, and defensible approach to the determination of candidate locations for the facilities. The results of the analyses support the locatiun of the Candidate Locations.

The GIS model is available for further use to add new criteria, to reevaluate the importance of present criteria, and to evaluate any new Candidate Locations.

As a result of these reviews, the "Above the 100 Year Flooding Elevation" should be redetermined based on and defined by topographic data, rather than being bounded along section lines. From field surveys, it is clear that Candidate Locations \#1 and \#9 are both above the elevation of concern, but the sections they are in were eliminated because of other low-lying areas within the same section. Use of topographic data would assuredly include them into the best areas shown nearby. 

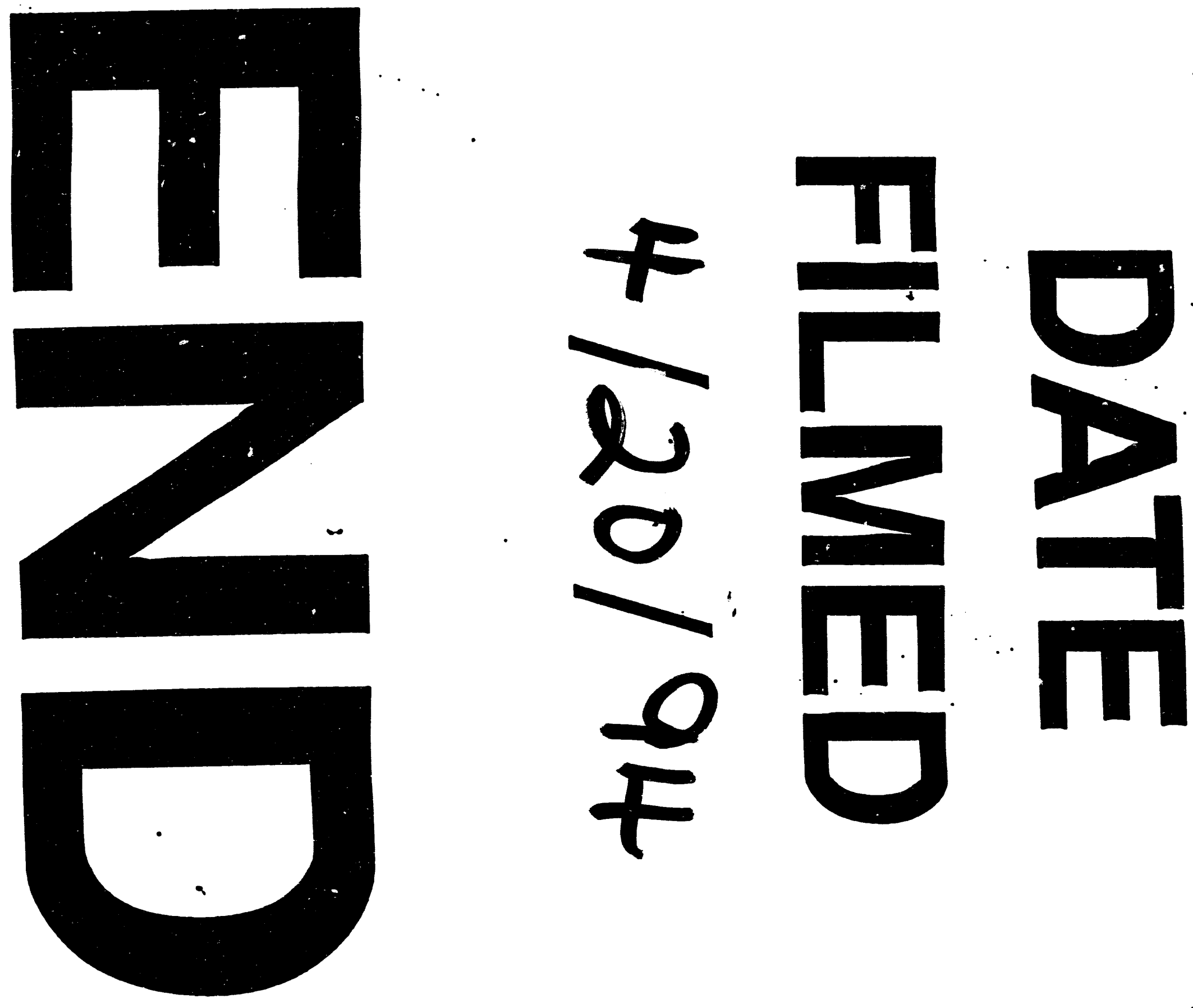

$F$

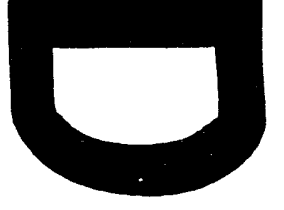


